\title{
Review \\ The Impact of Drought Stress on Soil Microbial Community, Enzyme Activities and Plants
}

\author{
Kalisa Bogati ${ }^{1, *}$ and Maciej Walczak ${ }^{1,2}$ \\ 1 Department of Environmental Microbiology and Biotechnology, Faculty of Biological and Veterinary Sciences, \\ Nicolaus Copernicus University, 87-100 Torun, Poland; walczak@umk.pl \\ 2 Bacto-Tech Sp. z o.o., Gagarina 5/102 Street, 87-100 Torun, Poland \\ * Correspondence: kalisabogati@doktorant.umk.pl
}

check for updates

Citation: Bogati, K.; Walczak, M. The Impact of Drought Stress on Soil Microbial Community, Enzyme Activities and Plants. Agronomy 2022, 12, 189. https://doi.org/10.3390/ agronomy12010189

Academic Editor:

Nikolaos Monokrousos

Received: 15 November 2021

Accepted: 5 January 2022

Published: 13 January 2022

Publisher's Note: MDPI stays neutra with regard to jurisdictional claims in published maps and institutional affiliations.

Copyright: (C) 2022 by the authors. Licensee MDPI, Basel, Switzerland. This article is an open access article distributed under the terms and conditions of the Creative Commons Attribution (CC BY) license (https:// creativecommons.org/licenses/by/ $4.0 /)$.

\begin{abstract}
Nowadays, the most significant consequence of climate change is drought stress. Drought is one of the important, alarming, and hazardous abiotic stresses responsible for the alterations in soil environment affecting soil organisms, including microorganisms and plants. It alters the activity and functional composition of soil microorganisms that are responsible for crucial ecosystem functions and services. These stress conditions decrease microbial abundance, disturb microbial structure, decline microbial activity, including enzyme production (e.g., such as oxidoreductases, hydrolases, dehydrogenase, catalase, urease, phosphatases, $\beta$-glucosidase) and nutrient cycling, leading to a decrease in soil fertility followed by lower plant productivity and loss in economy. Interestingly, the negative effects of drought on soil can be minimized by adding organic substances such as compost, sewage slugs, or municipal solid waste that increases the activity of soil enzymes. Drought directly affects plant morphology, anatomy, physiology, and biochemistry. Its effect on plants can also be observed by changes at the transcriptomic and metabolomic levels. However, in plants, it can be mitigated by rhizosphere microbial communities, especially by plant growth-promoting bacteria (PGPB) and fungi (PGPF) that adapt their structural and functional compositions to water scarcity. This review was undertaken to discuss the impacts of drought stress on soil microbial community abundance, structure and activity, and plant growth and development, including the role of soil microorganisms in this process. Microbial activity in the soil environment was considered in terms of soil enzyme activities, pools, fluxes, and processes of terrestrial carbon (C) and nitrogen (N) cycles. A deep understanding of many aspects is necessary to explore the impacts of these extreme climate change events. We also focus on addressing the possible ways such as genome editing, molecular analysis (metagenomics, transcriptomics, and metabolomics) towards finding better solutions for mitigating drought effects and managing agricultural practices under harsh condition in a profitable manner.
\end{abstract}

Keywords: climate change; water scarcity; soil microbiome; microbial activity; plant growth and development

\section{Introduction}

An increase in greenhouse gases, such as carbon dioxide $\left(\mathrm{CO}_{2}\right)$, methane $\left(\mathrm{CH}_{4}\right)$, and nitrous oxide $\left(\mathrm{N}_{2} \mathrm{O}\right)$, and atmospheric temperature, and depletion of water resources, being a consequence of anthropogenic activities, have driven climate change [1-5]. One of the important consequences of climate alteration is the occurrence of drought stress conditions. Drought stress in soil occurs when the water content or humidity in the soil and air is significantly low along with the high atmospheric temperature. This happens due to an uneven balance between the soil surface evaporation and plant transpiration followed by low soil water content [1]. Khan et al. [6] monitored global drought for almost two decades (2001-2019) using big geospatial datasets from Google Earth Engine and calculated drought indices, namely vegetation condition index (VCI), temperature condition index 
(TCI), soil moisture condition index (SMCI), and precipitation condition index (PCI). These indices showed continuous fluctuation of soil moisture and severe vegetation drought that affected $70 \%$ of the land globally. To date, many countries, including the USA, Australia, France, Russia, Turkey, Afghanistan, Iran, Mongolia, China, Brazil, Thailand, and Africa, have had historic events on the negative impact of drought, mainly on the agriculture and economy sector [6-10]. According to ICCP [2], each of the last four decades has been successively warmer than any decade that preceded it since 1850. Global surface temperatures were higher by 0.99 and $1.09^{\circ} \mathrm{C}$ in 2001-2020 and 2011-2020, respectively, than in 1850-1900, with larger increases over land $\left(1.59^{\circ} \mathrm{C}\right)$ than over the ocean $\left(0.88^{\circ} \mathrm{C}\right)$. In Europe, according to European Environment Agency (EEA; https:/ / www.eea.europa. $\mathrm{eu} / \mathrm{ims}$ / global-and-european-temperatures; 29 December 2021), land temperatures have increased even faster over the same period by around $1.9-2.02{ }^{\circ} \mathrm{C}[11,12]$ compared to the average values. Moreover, climate change scenarios predict a further decrease in average precipitation from May to October [12]. These trends show that the risk of soil drought in the vegetation growing season is high and may negatively affect crop yields. In Poland, a serious threat of agricultural drought was reported in the last few years, namely in 2010, 2011, 2013, 2015, 2017, and 2018 [13].

Drought is defined as a state of the total water capacity being within the range of $12-20 \%$ for a period of 16 days and can be distinguished from the water deficit, which is the state of water capacity falling below 30\% [14-17].

Drought is one of the most prevalent stresses that impact microbial community and activity, crop development, yield production, and quality [5,12]. A negative impact of drought on soil microbes can lead to a decrease in enzymes activity, loss in nutrient cycling (e.g., C, N, P), and soil fertility, thus plant productivity, especially of drought susceptible crops, and consequently economic outcomes $[5,18]$. The condition of the soil under drought stress strictly corresponds to plant growth and development. Drought directly affects plant morphology, physiology, and biochemistry [19]. It also reduces seed germination and seedling growth [20]. Plant responses to drought stress were also observed at transcriptomic and metabolomic levels [21]. Severe and long-term drought stress disturbs the availability of soil microbiota to the plant roots, significantly affecting their microbiome composition leading to modification of root structure and release of root exudates and disturbance of useful nutrients. The microbiome of plant roots changes during drought, favoring Actinobacteria and many other Gram-positive species, which substitute the Gram-negative taxa that are predominantly present in the rhizosphere [22]. Generally, soil microorganisms can enhance plant resistance to drought via different mechanisms, including the production of polysaccharides that improve soil structure and water holding capacity, synthesis of deaminase, indoleacetic acid (IAA), and proline (Pro), which induce drought stress tolerance in plants and improved water circulation through fungal mycelia [23]. Interestingly, the negative effect of drought on microorganisms can be mitigated by the addition of organic matter to soil [24]. Moreover, microbial activity (respiration rates) and soil microbial community structure can be modified by drought-associated phytohormones such as abscisic acid (ABA), jasmonic acid (JA), and 1-aminocyclopropane-1-carboxylic acid (ACC), but adaptation to prolonged drought modifies the responses of soil microbial communities to these hormones [25].

Despite negative aspects of changes caused by drought, such severe environmental conditions can induce interesting adaptations in microbes and plants that allow them to survive and reproduce. These adaptations can lead to the emergence of new functional groups in the ecosystem or serve as an important tool for improving agricultural practices and plant breeding programs $[4,25]$. Such drought-tolerant microorganisms and their traits could be used in the search for efficient compounds of biopreparations supporting plant growth [19].

This review was undertaken to discuss the impact of drought stress on soil microbial community abundance, structure, and activities, thus soil enzyme activities, pools, fluxes, and processes of terrestrial carbon and nitrogen cycles, and plant growth and development, 
including the role of soil microorganisms in this process. A deep understanding of many aspects is necessary to explore the impacts of these extreme climate change events.

\section{Impact of Drought Stress on Microbial Communities and Enzyme Activities}

Prolonged drought has a significant impact on the abundance, structure, and activity of the soil microbiome [12]. The potential metabolic microbial activity decreases with a reduction in soil water potential, followed by lowering nutrient mineralization and respiration [26]. However, structural and/or functional adaptation of microbial communities in response to drought depends on soil type, farming system, and plant cultivars [22], as discussed later.

In this section effect of drought in soils on microbial structure and enzyme activity, and consequently on nutrient cycling and soil fertility, is discussed (Figure 1).

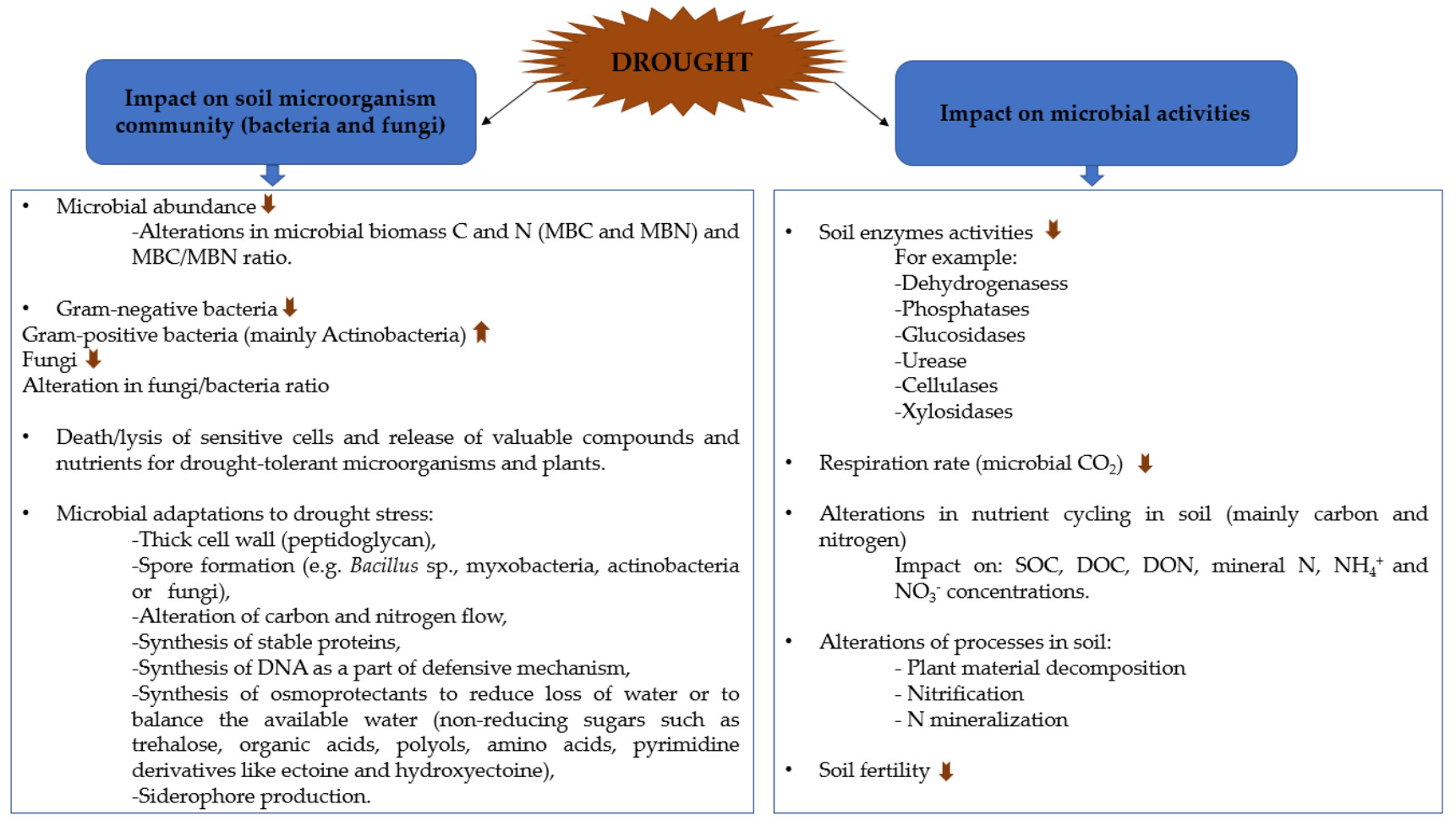

Figure 1. Schematic representation on the impact of drought stress on microbial communities and activities.

\subsection{Effect of Drought on Microbial Communities}

\subsubsection{Microbial Adaptations to Drought Stress}

It is known that thick peptidoglycan in the cell wall of Gram-positive bacteria is responsible for their higher resistance towards drought when compared to Gram-negative bacteria. Microbes either die or become dormant during immediate stressful environments, whereas on the arrival of favorable conditions, the dormant forms regain their activity. In addition, dead microbial cells release many valuable compounds such as nitrogen, phosphates, amino acids, polyols, nutrients that can be beneficial to other microbes and plants. These microorganisms that form spores (e.g., Bacillus sp., myxobacteria, filamentous actinobacteria, or fungi) are resistant to abiotic factors, including drought stress, and able to survive for a long time in dormant forms. However, microbes might develop many tolerance mechanisms, some of which are energetically expensive, such as these related to the regulation of resistance genes, alteration of carbon and nitrogen flow, synthesis of stable proteins and osmolytes, which reduce loss of water or balance the available water [27,28].

Desiccation-tolerant microorganisms, e.g., Rhodococcus jostii RHA1 [29], Microbacterium sp. 3J1, Arthrobacter siccitolerans 4J27, Rhodococcus sp. 4J2A2 [30], Rhodococcus opacus 
PD630 [31], Lactobacillus paracasei [32], and Pseudomonas putida KT2440 [33] are known to overproduce various molecules such as non-reducing sugars (trehalose), organic acids, polyols, amino acids, (rich in hydroxyl groups), pyrimidine derivatives such as ectoine and hydroxyectoine [30,33-38] responsible for the protection of cells from drought stress that are called xeroprotectants. These molecules can also be taken up by non-synthesizing microorganisms in drought conditions [39,40]. A study by García-Fontana et al. [41] on desiccation-tolerant microorganisms of Microbacterium sp. 3J1 showed overexpression of genes encoding for enzymes involved in DNA syntheses such as topoisomerases, DNA polymerases, and gyrases. This resulted in an increase in DNA production in cells as part of their defensive mechanisms to protect protein structures and functions from drying, confirmed by RNA-seq analysis. In addition, siderophores, secondary metabolites that scavenge iron from environmental stocks and deliver it to cells via specific receptors, are believed to help bacteria to thrive in such environments [42]. It was proved that siderophore producing Azospirillum sp. strain B2 was most resistant to drought stress and used as an inoculant for wheat can alleviate drought stress on plant growth and yield [42].

2.1.2. Effect of Drought Stress on Microbial Community in Different Type of Soils or under Soil Modifications

Severe drought conditions modify the microbial community structure, size, and activity in soils. However, their effect on the microbial structure is more significant in soils with low organic matter content [12,43]. For example, controlled conditions of drought stress-induced changes in the relative abundances of particular phyla present in sandy and loamy soils. Among six phyla, namely Actinobacteria, Bacteroidetes, Firmicutes, Planctomycetes, Protecobacteria, and Verrucomicrobia that accounted for $>95 \%$ of the total bacterial abundance, the Actinobacteria (especially genera Gaiella and Nocarioides) were most prevalent in analyzed samples. While relative abundance of Proteobacteria, being corticotrophs, and Verrucomicrobia decreased significantly [12]. Baldrian et al. [44], based on phospholipid fatty acid (PLFA) analyses, recorded that with the decrease in soil moisture content, the microbial (bacterial and fungal biomass) also decreased. In contrast, Bastida et al. [45] showed that drought influenced the fungal PLFA biomarker but not the bacterial PLFA biomarkers. Interestingly, in other studies on drought impact, a higher abundance of Firmicutes in soil that has previously been exposed to such stress conditions was observed [46]. This indicates that soils under repetitive drought events exhibit lower stress mortality. This can be a consequence of microbial adaptation that has been developed.

Castro et al. [47] reported that drought-induced reductions in labile carbon and nitrogen entering the rhizosphere might be a contributing factor in the loss of microbial phyla such as Verrucomicrobia, Proteobacteria and Acidobacteria, which are heterotrophs and sensitive to nitrogen ratios. It has been well-documented that exogenous organic matter in the form of sludge or compost amendments plays an important role in protecting soil microbial community and microbially-mediated processes in semiarid or arid soils [43]. They recorded that the total and Gram-positive bacteria and total monounsaturated PLFA were affected significantly by drought only in the unamended soil. The alterations in bacterial community composition under drought stress were also observed in two types of wheat rhizosphere soils (Chernozem and Luvisoil) [22]. The Luvisol soil showed a decrease in Gram-negative bacteria and persistence of actinomycetes under drought conditions. However, at the same time, actinobacteria diversity was lower in Luvisol than in Chernozem soil. Therefore, in the case of Luvisol soil, which is less rich in organic matter content, the effect of drought was more prominent [22]. It is another proof that the application of organic residues can be proposed as an adequate strategy against soil degradation in semiarid environments. However, the interactions between organic amendments and drought are not fully known $[12,43,45]$.

Furthermore, microbial community structure and microbial activity (respiration rates) in soil under drought stress can be modified by drought-associated phytohormones (ABA, JA, and ACC) [25]. However, the authors demonstrated the adaptation of soil microbial 
communities to the long-term drought that was observed by their response to plant stress hormones. All three phytohormones significantly declined Gram-positive biomarkers in drought soils. That is interesting, as these bacteria are generally assumed to be more stresstolerant than Gram-negative bacteria [48]. Overall, the adaptation of microbial communitylevel to drought stress often involves shifts towards organisms with greater tolerance to water deficit and slow-growing taxa with a reduced metabolic capacity $[12,25,49]$. Authors speculated that the decrease in Gram-positive biomarker abundance after treatment with all three phytohormones indicates drought-adapted bacteria that responded negatively to stress signaling by investing resources in survival strategies such as dormancy, osmolytes, or spore production instead of growth and turnover. Further, they claimed that droughtadapted soil microbial communities might perceive these phytohormones as signals of impending water stress rather than as a substrate for growth [25]. Moreover, they found that the abundance of Gram-negative biomarkers remained unchanged in droughted soils but increased with ABA, ACC, and JA addition to control soils. Therefore, the Grampositive:Gram-negative bacteria ratio increased in drought stress. Furthermore, they also found that in response to all phytohormones, the relative abundance of saprophytic fungal and arbuscular mycorrhiza (AM) biomarkers increased in droughted soils [25].

Drought stress is known to hamper the availability of soil microbiota to the plants and significantly affect root microbiome composition. The differences in the abundance of root-associated microbial communities at endosphere and rhizosphere levels during monsoon and dry seasons were reported by Naylor et al. [50]. They found that fungal communities in soils and rhizosphere were unaffected, whereas the class Actinobacteria decreased significantly in $\alpha$-diversity in roots with also a decline in Acidobacteria and Deltaproteobacteria. On the other hand, they also noticed an increase in enrichment of Actinobacteria (Saccharopolyspora, Glycomyces, and Actinopolymorpha) under drought in the root endosphere than in rhizosphere or bulk soil itself.

\subsection{Effect of Drought on Soil Enzyme Activities}

Soil enzymes are produced by animals [51], plants [52], and microorganisms. They are prominently secreted by microbes and reflect microbial activity in this biome [53]. Soil microorganisms mainly synthesize extracellular enzymes such as $\beta$-glucosidase, hydrolases urease, phosphatase, glycosylating enzymes, cellulase, amylase, cyclomaltodextrinase, chitinase, and many more [43,54-56]. Other enzymes such as dehydrogenases or catalase are intracellular. Therefore, soil enzymes play a vital role in the biodegradation of organic compounds in soil and become the most delicate indicator of changes in microbial activities (termed as "sensors") that occur in the soil environment in response to different factors including drought $[43,57]$.

The reports on the effect of drought on different soil enzymes are limited. Generally, these effects are uncertain or not easy to predict [58]. However, a decrease of moisture content in soils decreases microbial biomass and thus soil enzyme activities $[44,59,60]$. Baldrian et al. [44] observed seasonal changes in the activity of enzymes and the abundance of microorganisms correlated with the water content in the soil. The significant decrease in soil microbial communities and reduction of $>50 \%$ activity of laccase, $\mathrm{Mn}$ peroxidase, endo- $1,4-\beta$-glucanase, endo- $1,4-\beta$-xylanase, cellobiohydrolase, $\beta$-glucosidase, $\beta$-xylosidase, chitinase, and acid phosphatase enzymes were recorded in soils with low water content $\left(0.30-0.40 \mathrm{~g} \mathrm{~g}^{-1}\right)$ when compared to control samples with higher water content $\left(0.60-0.70 \mathrm{~g} \mathrm{~g}^{-1}\right)$. In other studies, it was found that drought-affected activity of C-cycling enzymes (cellulases, glucosidases, and xylosidases) in the rhizosphere of two wheat cultivars in loamy Chernozem and sandy Luvisol soils in organic and conventional farming. For 'Dichter' wheat cultivar, enzymatic activities were decreased in Chernozem soil in both farming types. While in Luvisoil, increased activity of glucosidases and xylosidases was recorded in organic farming. In the case of 'RGT-Reform' wheat cultivar, drought negatively affected xylosidase and glucosidase activities in the Chernozem soil but promoted glucosidase activities in Luvisol [22]. Drought impact on sediment revealed de- 
crease in esterase $(0.5 \%$ /day) [61], $\beta$-glucosidase ( $>50 \%)$ [62], leucine aminopeptidase [63], phosphatase ( $>50 \%$ ) [64], and phenol oxidase (PO) [63] activities. In the case of Mediterranean evergreen oak forests, a reduction of 10 and $21 \%$ of soil moisture in plots (by water runoff) decreased urease activity by $10-67 \%$ and $42-60 \%$, protease activity by $15-66 \%$ and $35-45 \%$, and $\beta$-glucosidase activity by $10-80 \%$ and $35-83 \%$ depending on the annual period (spring and autumn) and soil depth $(0-15$ and $15-30 \mathrm{~cm})$. The lowest activities of these enzymes were observed in autumn and at a greater depth. The significant reduction of acid phosphatase activity (by 31-40\%) was observed only when the moisture content in the soil was reduced by $21 \%$. The phenolooxidases (laccases, Mn-peroxidases, lignin-peroxidases, and tyrosinases) activities in evergreen oak forests were studied by Cricquet et al. [65]. They observed a significant increase in laccase and Mn-peroxidase activities in autumn when compared to other months, while other phenoloxidases, lignin-peroxidases, and tyrosinases were never detected in analyzed samples. However, in this study, analyzed forest plots were not artificially dried by water runoff [65]. Similarly, in other studies by Criqet et al., acid phosphatase activities were significantly higher from November to January and decreased in other months [66]. These highest activities $\left(>6 \times 10^{-2} \mathrm{U} \mathrm{g}^{-1} \mathrm{DM}\right)$ correlated with high soil moisture content (around 65-70\%). The lowest enzyme activities $\left(1.2 \times 10^{-2} \mathrm{U} \mathrm{g}^{-1} \mathrm{DM}\right)$ were recorded in July, when soil moisture content was found to be nearly $15 \%$. The alkaline phosphatase was undetectable or at low activity when compared with acid phosphatase activities but highest between May and October. A significant decrease in enzymatic activity of dehydrogenases and phosphatases in both loamy and sandy soils was observed during the first month under drought stress, while after two months of stress conditions, activity of dehydrogenases was even three times less when compared to the control sample under the optimal moisture level [12]. However, the level of dehydrogenase activity was considerably higher in the loamy soil than in sandy soil, which can be related to higher organic matter content in the former one [12,67], but the aspect of the presence of organic residues on microbial abundance and activity in soil will be discussed later in this section.

Moreover, relatively high soil exoenzyme ( $\beta$-glucosidase, $\beta$-xylosidase, $\alpha$-glucosidase (AG), $\beta$-D-cellobiosidase (CBH), N-acetyl- $\beta$-glucosaminidase, acid phosphatase, leucine amino peptidase, phenol oxidase, and peroxidase (PER)) activities were observed during summer girdling of lodgepole pine (that was complete removal of the bark from around the trunk of a tree) but decreased after girdling in response to drought [68].

\subsection{Effect of Drought on Microbial Activity}

Severe drought conditions, despite enzyme activities, may compromise nutrient availability in the soil, as proved in the study by Hueso et al. [43]. They found high soil dehydrogenase activity ( $34 \%$ of the total variability), a decrease of other enzyme activity, high basal respiration, and water-soluble carbon in stressed soil compared to well-watered soils. Increased levels of water-soluble carbon may be linked to an increase in carbohydrate production (52\% of the total variability) due to the fact that few soil microbes produce biological polymers in response to low water conditions. Perhaps, drought can cause the death of sensitive microorganisms unable to thrive under such harsh conditions, which results in the release of substrates from dead cells into their surroundings, in turn providing accessible nutrients to the drought-resistant microorganisms or survivors. In addition, decreased metabolic activity of the soil microbial community was also observed under drought conditions, in turn leading to a decrease in mineralization of carbon, nitrogen, and phosphorus biological cycles or pathways [43]. This suggests that a large community of active microbial biomass did not survive during long drought stress periods, resulting in the decline of overall soil microbial functional diversity $[12,18,69]$.

Drought strongly affects soil nitrogen cycling by inhibiting nitrification [12]. The soil nitrification potential (NP) is a highly sensitive parameter, which reflects the response of soil microorganisms to environmental factors, e.g., temperature or moisture content [70]. It describes the potential activity of a specialized group of autotrophic bacteria, namely 
ammonia-oxidizing bacteria (mainly genera Nitrosomonas and Nitrosospira) that are responsible for the first phase of nitrification [71]. Siebielec et al. [12] showed that after one month drought period, the NP activity was reduced by 70 and $80 \%$ in the loamy and sandy soils, respectively. These results indicate that the resistance of sandy soil with low organic matter content to drought stress was lower than that in loamy soil. Interestingly, the compost application to the sandy soils only slightly reduced the negative effects of drought on soil nitrifying bacteria [12].

Deng et al. [72] investigated soil $\mathrm{C}$ and $\mathrm{N}$ pools and fluxes in response to drought in three different ecosystems, namely forests, grasslands, and shrublands, conducting meta-data analyses, wherein a huge amount of data was collected. These data were taken from 148 reports and included 1815 sampling data at 134 sites across the globe and were mainly focused on short-term drought. They analyzed vegetation-related properties, soil pools of $\mathrm{C}$ and $\mathrm{N}$ and their fluxes, soil microbial biomass, and activity of enzymes (Table 1). Overall, the effects of drought on soil $\mathrm{C}$ and $\mathrm{N}$ cycles were regulated by the ecosystem type, drought duration, and intensity. The latter two parameters intensified all effects. The soil organic carbon (SOC) concentration was decreased across the globe as a consequence of decreased litter input and decomposition under drought conditions. Drought also negatively affected root biomass. Microbial respiration (microbial $\mathrm{CO}_{2}$ ) was increased, especially in forests and grasslands. Moreover, drought increased the contents of dissolved organic carbon (DOC) by 59\% and dissolved organic nitrogen (DON) by 33\% due to decreased mineralization and higher stability of dissolved organic matter. Although the soil mineral nitrogen (SMN) content increased (by 31\%), the nitrogen mineralization and nitrification rates decreased (by 5.7 and $13.8 \%$, respectively), thus total nitrogen concentration unchanged. Globally, $\mathrm{NH}_{4}{ }^{+}$and $\mathrm{NO}_{3}{ }^{-}$increased (52 and $16 \%$, respectively), but in forest soils, an increase of $\mathrm{NH}_{4}{ }^{+}$concentrations corresponded to an $11.3 \%$ decrease of $\mathrm{NO}_{3}{ }^{-}$, thus reflected the increase of $\mathrm{N}$ mineralization rate, but a decrease of nitrification rate. In shrublands, unlike forest soils, the concentration of $\mathrm{NH}_{4}{ }^{+}$slightly increased, but $\mathrm{NO}_{3}{ }^{-}$ increased significantly (69.2\%). Since nitrogen mineralization rate was unaffected, but nitrification rate strongly decreased (by $56.4 \%$ ), this might be a consequence of less $\mathrm{N}$ uptake by plants under drought. Drought negatively affected microbial biomass nitrogen (MBN) content. Thus, the ratio of microbial biomass carbon MBC to MBN increased, similarly to fungal/bacterial ratio and enzyme activities across the globe (Table 1).

Table 1. Effects of drought on soil $\mathrm{C}$ and $\mathrm{N}$ dynamics in three different ecosystems according to the study of Deng et al. [72].

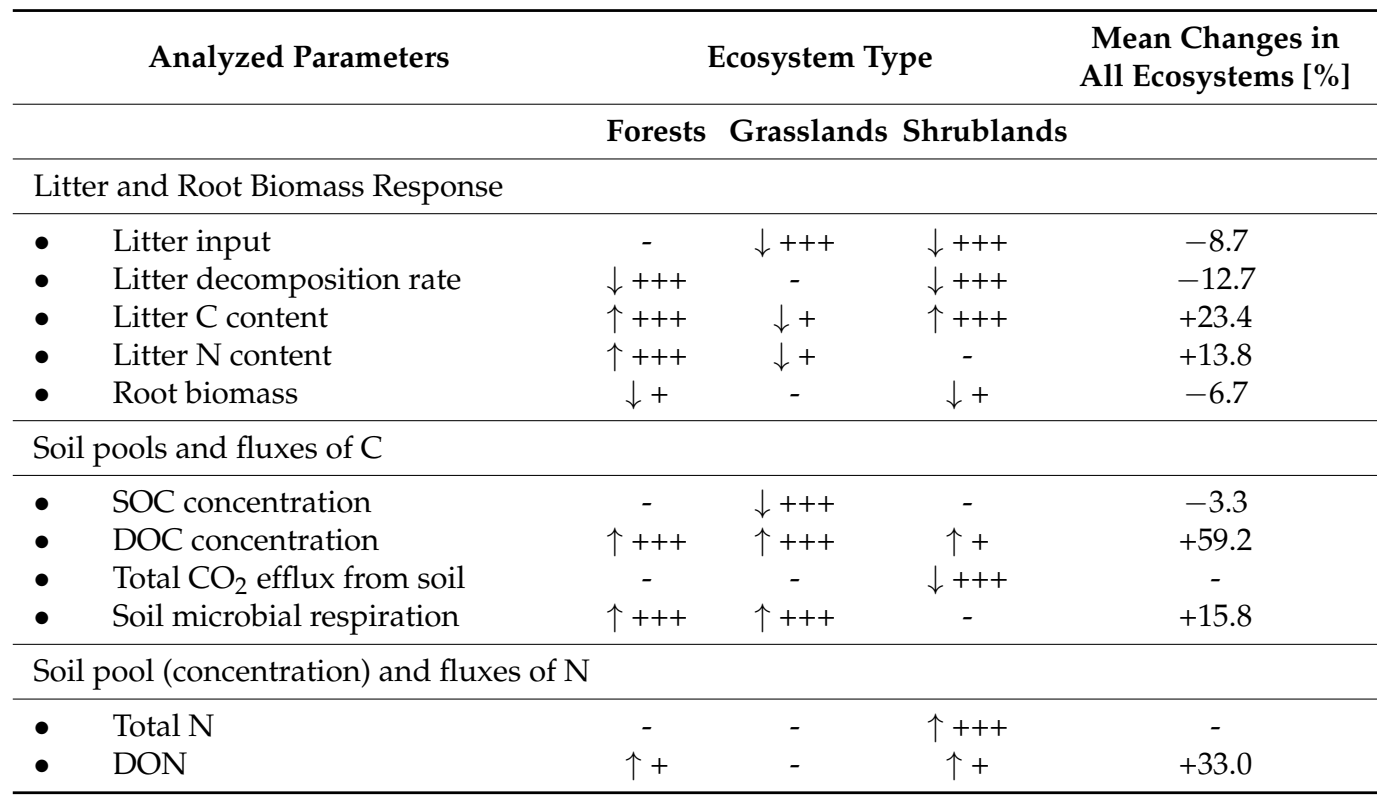


Table 1. Cont.

\begin{tabular}{|c|c|c|c|c|}
\hline \multirow[t]{2}{*}{ Analyzed Parameters } & \multicolumn{3}{|c|}{ Ecosystem Type } & \multirow{2}{*}{$\begin{array}{l}\text { Mean Changes in } \\
\text { All Ecosystems [\%] }\end{array}$} \\
\hline & Forests & Grasslands & Shrublands & \\
\hline - $\mathrm{NH}_{4}^{+}$ & $\uparrow+++$ & $\uparrow+$ & $\uparrow+$ & +52.5 \\
\hline - $\quad \mathrm{NO}_{3}{ }^{-}$ & $\downarrow+++$ & $\uparrow+$ & $\uparrow+++$ & +16.0 \\
\hline - $\quad \mathrm{SMN}$ & $\uparrow+++$ & $\uparrow+$ & $\uparrow+$ & +31.0 \\
\hline - $\quad$ nitrification & $\downarrow+$ & - & $\downarrow+++$ & -13.8 \\
\hline - $\quad \mathrm{N}$ mineralization & $\downarrow+$ & - & $\downarrow+$ & -5.7 \\
\hline - $\quad$ Soil microbial biomass & - & - & - & - \\
\hline - $\quad \mathrm{MBC}$ & - & - & - & +2.2 \\
\hline - $\quad \mathrm{MBN}$ & $\downarrow+$ & $\downarrow+$ & $\downarrow+$ & -10.4 \\
\hline - $\quad \mathrm{MBC} / \mathrm{MBN}$ ratio & $\uparrow+++$ & $\uparrow+++$ & $\uparrow+$ & +29.7 \\
\hline - $\quad \mathrm{F} / \mathrm{B}$ ratio & $\uparrow+$ & $\uparrow+$ & - & +15.6 \\
\hline \multicolumn{5}{|l|}{ Soil enzyme activities } \\
\hline - $\quad \beta$-glucosidase & $\downarrow+$ & $\uparrow+$ & $\downarrow+$ & +3.5 \\
\hline - urease & $\downarrow+++$ & $\uparrow+++$ & $\downarrow+$ & +12.7 \\
\hline
\end{tabular}

\subsection{Mitigation of Drought Effects on Microbial Activity by Soil Amendments}

The negative effect of drought in the soil can be minimized by adding organic substances. The addition of different types of organic matter, namely compost (COM), sewage sludge (SS), and municipal solid waste (MSW) to the arid soil increased the activity of soil enzymes such as oxidoreductases, hydrolases, dehydrogenase, catalase, urease, phosphatases, $\beta$-glucosidase, casein- and N- $\alpha$-benzoyl-L-argininamide (BAA)-hydrolyzing proteases [24], probably as a consequence of the increase in microbial biomass [43], as mentioned previously.

Moreover, microbial activity (soil respiration) in drought soils can be modified by the addition of plant hormones, namely ABA, JA, and ACC. However, soil respiration response to phytohormones depended on their dose. For example, the addition of $1 \mathrm{mM}$ ABA two times increased microbial activity in droughted soil when compared to control soil, but lower ABA concentrations, namely $1 \mu \mathrm{M}$ and $1 \mathrm{nM}$, did not affect the respiration rate of soil samples. Interestingly, both ACC and JA in low and high concentrations increased microbial activity but not in intermediate concentrations. Respiration from droughted soils was 1.5 times higher than from the control samples treated with ACC. In the case of JA, the lowest concentration of JA $(1 \mathrm{nM})$ had the largest effect on respiration in droughted and control soils [25]. Authors suggested that increased respiration rates in soils in response to phytohormones could be a result of hormone utilization as sources of $\mathrm{C}$ and $\mathrm{N}$ by bulk soil microorganisms. However, such a relationship was confirmed only in the case of ABA addition [25]. Therefore, further studies are required.

\section{Plant Morphological, Physiological, Biochemical Responses towards Drought Stress}

In general, plants are exposed to numerous environmental stresses in the course of their different stages of growth irrespective of the natural or agricultural environment [73] The occurrence of environmental alterations has developed various adaptations in plants for their survival in harsh conditions [1]. Common prominent environmental stress such as drought caused due to dwindling of water resources is the main foundation in affecting overall plant productivity [73]. The plant responds to drought stress at different levels-morphological, anatomical, biochemical, physiological, and molecular [73-76] (Figure 2). 


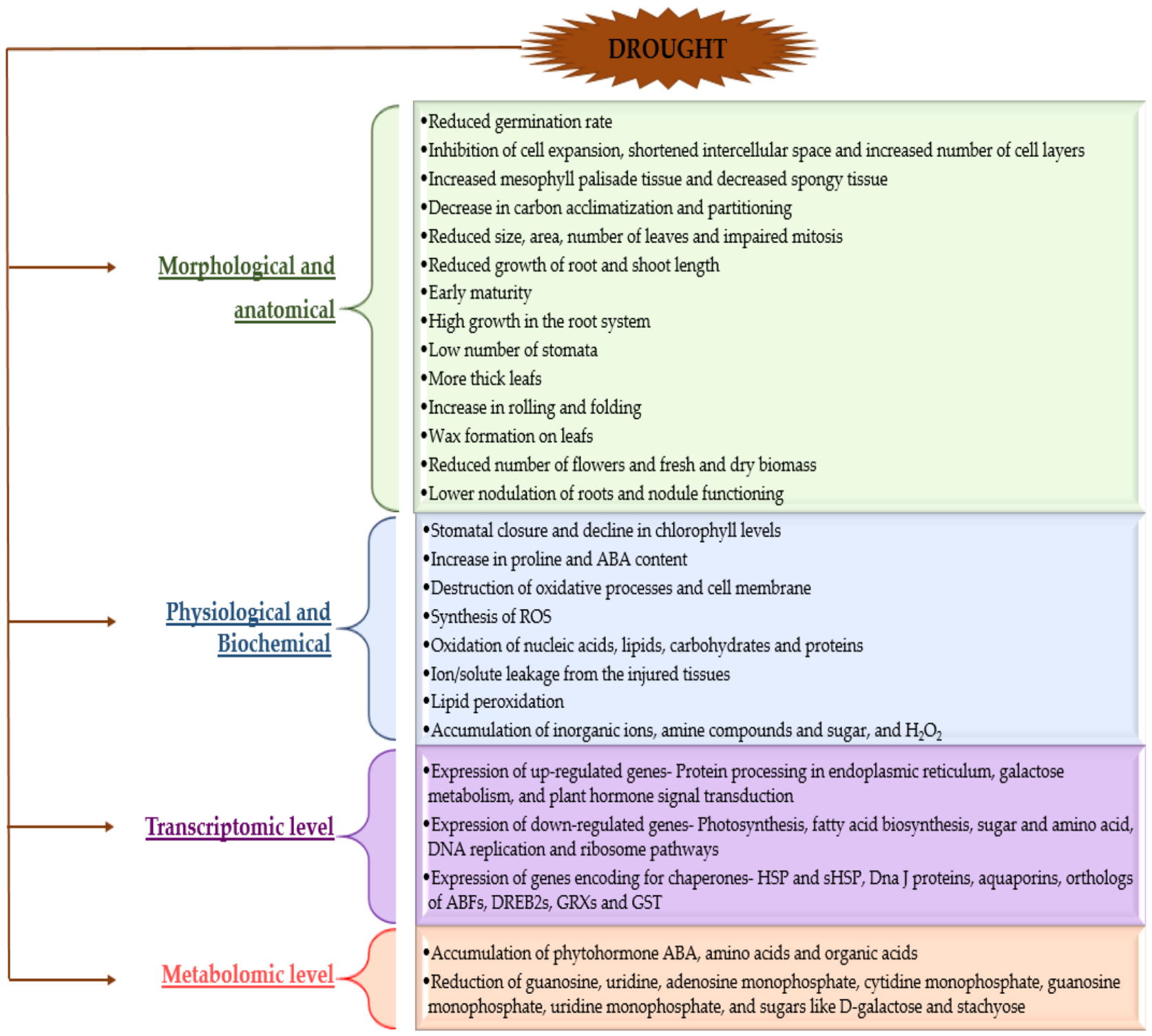

Figure 2. Morphological, anatomical, physiological, biochemical, and molecular responses of plants to drought stress.

\subsection{Morphological and Anatomical Changes in Plants in Response to Drought Stress}

Drought might affect plants at each stage in their growth cycle, including seed germination. Water scarcity or drought reduces germination rate leading to reduction of seedling emergence or inhibition and further growth in plants [20]. Drought stress disturbs the seedling growth because of cell expansion inhibition, decrease in carbon acclimatization, and partitioning [77]. The decrease in plant height is mainly due to decreased cell expansion, increased leaf shedding, and impaired mitosis under drought conditions [78]. Reduction in seedling characteristics in drought-stressed plant seeds such as Brassica napus was reported by many authors [79-81]. Morphological changes in plant under drought stress involve reduced size, area, and number of leaves as well as the growth of root and shoot length due to stimulation of the ABA precursor called ACC that prevents the growth of root, with early maturity, high growth in the root system, low number of stomata, more thick leaves with an increase in rolling and folding and wax formation in order to prevent loss of water from leaves as well as from roots $[1,25,73]$. In addition, plant leaves tend to increase mesophyll palisade tissue, decrease spongy tissue, increase the number of cell layers, but decrease the volume and shorten the intercellular space to adopt drought, as 
found in two avocado cultivars [82]. Overall, the change of leaf area, which directly affects plant photosynthesis and yield, is one of the most easily observed features of plant leaves under drought stress [78]. Plants under drought stress have reduced the number of flowers and fresh and dry biomass [19]. Drought stress causes a decrease in nodulation [83] and nodule functioning [75]. In plants, the water deficit conditions are recognized in roots, and then several molecular signals move from roots to shoots. Consequently, abscisic acid (ABA) phytohormone mediates resistance to drought stress by regulating stomatal closure and synthesizing stress-responsive gene expression in leaves, thereby affecting reduction in transpiration [84-87].

\subsection{Physiological and Biochemical Changes in Plants in Response to Drought Stress}

Photosynthesis, as mentioned above, is one of the main processes affected by water stress leading to a decrease in plant growth. The decrease of photosynthetic rate under drought stress is the result of stomatal and non-stomatal limitations. The stomatal limitation is believed to be the main factor of photosynthetic rate decrease under mild drought while non-stomatal limitation under severe drought conditions. Stomatal closure limits leaf absorption of $\mathrm{CO}_{2}$ and prevents transpiration water loss due to turgor pressure and/or reduced water potential [78]. Non-stomatal factors are related to the decrease of activity or content of component, such as ribulose-1,5-bisphosphate (RuBP) or ribulose-1,5-bisphosphate carboxylase/oxygenase (RuBisCo) involved in the photosynthetic assimilation process and the efficiency of photosystem II (FPSII), respectively $[88,89]$.

Biochemical changes include the decline in chlorophyll levels, increase in Pro content, destruction of oxidative processes by the production of antioxidative enzymes, increase in ABA levels, and synthesis of reactive oxygen species (ROS) [73]. Drought stress inhibits the chlorophyll synthesis (chlorophyll ' $a$ ' and ' $b$ '), changes in chlorophyll ' $a$ ' /' $b$ ' ratio, especially in drought-sensitive plant cultivars, thereby the efficiency of photosynthetic apparatus, resulting in the production of ROS. They are formed as a consequence of photosynthetic electron transport reactions in the circumstances of a flooded electron flow system with a decreased pool size of electron acceptors [90-92]. Therefore, chlorophyll decline is one of the most injurious concerns of drought stress. In response to the deterioration of photosynthetic apparatus, synthesized ROS causes oxidation of carbohydrates, proteins, nucleic acids, lipids, as well as the destruction of the cell membrane [90,93]. Lipid peroxidation leads to overproduction of malondialdehyde (MDA), which is one of the indicators of oxidative damage [21,94-96]. Moreover, the accumulation of metabolites such as inorganic ions $\left(\mathrm{Na}^{+}\right.$, $\mathrm{K}^{+}, \mathrm{H}^{+}$), amino acid (Pro), amine compounds (glycine betaine and polyamines), and sugar (trehalose, fructan, mannitol, etc.) in plants occurs for the regulation of osmotic potential under drought stress conditions. These substances are usually of small molecular weight, highly soluble, and have little toxicity to cells. They can maintain the normal osmotic pressure level, protect the protein activity and cell membrane structure, and so on [97-100]. For example, the contents of Pro, glycine betaine, total soluble carbohydrate, and sucrose were significantly increased due to drought stress in several pistachio genotypes, as shown in the study of Khoyerdi et al. [101].

Pro is well-known for its acclimatizing roles in plant stress tolerance, works as a molecular chaperone to alleviate the configuration of proteins, and its high concentration is considered an indicator of tolerance to water stress [102-105]. These amino acids are preferentially stored in plant vacuoles and transported to the cytoplasm during osmotic stress. Increase of its concentration in cytoplasm leads to reduction of the osmotic potential, thus that the cell can still absorb extracellular water thus, maintaining the cell protoplasm and the external environment of osmotic balance. Proline can reduce the oxygen damage caused by stress through chelating singlet oxygen and hydroxyl radical or stimulate the activity of POD, catalase (CAT), superoxide dismutase (SOD), polyphenol oxidase (PPO), and other enzymes in plants to remove drought stress generated ROS. It has a strong ability to hydrate and bind to proteins, therefore, stabilizing and protecting biological macromolecules, maintaining their structure and activity, and cell membrane structures [78]. 
Similarly, glycine betaine, as a water-soluble substance with amphoteric properties, can bind to both hydrophilic and hydrophobic regions of biological macromolecules such as enzymes and acts as an osmotic regulator. It was found that glycine betaine protects the key enzymes of the dicarboxylic acid cycle, terminal oxidases, and the photosystem, which have important physiological significance in maintaining proper respiration and photosynthesis of plants [106]. However, the osmotic regulations can only temporary improve plant resistance to drought stress. If drought stress is severe, the turgor pressure of plants cannot be maintained [78].

In addition, plants under drought stress can synthesize drought-induced functional (e.g., late embryogenesis abundant proteins, including dehydrins and aquaporins) and regulatory proteins (protein kinases, phospholipase C, phospholipase D, G protein, calmodulin, transcription factors, and some signaling factors). They are involved in the protection of ion channel functioning, ROS scavenging, water molecule binding, enzyme activity (e.g., SOD, POD), PSII proteins, membrane structure, and water transport at cellular or subcellular levels or in signal transduction or gene expression regulation, and play indirect protective roles in water stress [78].

Reactive oxygen species (ROS) include superoxide radical $\mathrm{O}_{2}{ }^{-}, \mathrm{H}_{2} \mathrm{O}_{2}$, singlet oxygen ${ }^{1} \mathrm{O}_{2}$, hydroxyl radical $\cdot \mathrm{OH}$, and organic oxygen radical ( $\left.\mathrm{RO}, \mathrm{ROO}\right)$, etc. They can be produced in plants through many metabolic pathways, namely in the process of photosynthesis and respiration, as well as in other processes in mitochondria, chloroplasts, and peroxisomes. However, some other organelles or parts with high oxidation activity or strong electron transfer function may also be involved in ROS production. In plants under drought stress, ROS are overproduced mainly by chloroplasts and mitochondria [107-109]. For example, $\cdot \mathrm{OH}$ can directly induce the peroxidation decomposition of the unsaturated fatty acid chain in phospholipids, thus destroying of membrane structure. In addition, ROS can destroy almost all proteins or enzymes, break, degrade, or modify single or double strands of DNA [110-112].

For scavenging the high levels of ROS, plants have developed complex enzymatic and non-enzymatic systems. The former includes superoxide dismutase (SOD), glutathione peroxidase (GPX), catalase (CAT), and ascorbate peroxidase (APX), dehydroascorbate reductase (DHAR), monodehydroascorbate reductase (MDHAR), and glutathione reductase (GR), while the latter a low molecular weight antioxidant, namely reduced glutathione (GSH), ascorbic acid (AsA), vitamin E, mannitol, flavonoids and carotenoids [78,113,114]. SOD and APX are mainly localized in cytoplasm and chloroplasts, CAT in peroxisomes, GPX mainly in cytoplasm and mitochondria, and GR in chloroplasts [78]. The high amount of $\mathrm{H}_{2} \mathrm{O}_{2}$ in drought-stressed plants is generated as a consequence of SOD activity, which transforms superoxide radicals $\left(\mathrm{O}_{2}{ }^{-}\right)$to $\mathrm{H}_{2} \mathrm{O}_{2}$ and $\mathrm{O}_{2}$. Generally, SOD activity increased under mild or short-term water stress but decreased under severe or long-term water stress [78]. Generated $\mathrm{H}_{2} \mathrm{O}_{2}$ being toxic to plant cells is reduced to water by POD and APX or converted to oxygen and water by CAT [97]. Moreover, GR, DHAR, and MDHAR are also very important $\mathrm{H}_{2} \mathrm{O}_{2}$ scavenging enzymes [78]. All of these scavenging systems normalize $\mathrm{H}_{2} \mathrm{O}_{2}$ levels in plants [115]. Non-enzymatic ROS scavenging system involves substances that can react directly with ROS (GSH, AsA), act as substrates of enzymes in the ROS scavenging mechanism, or, as in the case of vitamins, by scavenging oxygen free radicals, preventing lipid peroxidation directly. GSH-AsA cycle is the main pathway of GSH and AsA regeneration and antioxidant system in plants, which stabilizes the ROS level in the chloroplasts of plants [116].

Sun et al. [117] analyzed the response of nearly 60 different plant species and their cultivars (e.g., oilseed rape, fava bean, maize, wheat, mustard, mung bean, soybean, Euphorbia tirucalli, Coffea arabica, oak, cedar, Norway spruce, apple plants, and many more) to water stress (the median water stress intensity of 0.52 and experimental duration of 36 days) based on several independent variables of plant tissues such as leaf, shoots, roots, and whole plants. Water stress intensity was calculated as the proportional reduction in soil moisture (reduced soil moisture under water stress treatment/soil moisture in the control 
groups). They conducted meta-data analyses wherein a huge amount of data was collected from 1301 paired observations of 84 studies across the globe and estimated the impact of short-term drought on plants. Based on the morphology, physiology, and functionalities of plants, they analyzed plant growth (dry weight and protein), photosynthetic characteristics (chlorophyll; maximal efficiency of PSII photochemistry; photochemical quenching coefficient), plasma membrane permeability (ROS, MDA, and electrolyte leakage), enzymatic antioxidants (APX, GR, glutathione reductase, CAT, POD, SOD) and nonenzymatic antioxidants (ABA, AsA, Pro, carotenoids, soluble sugars). Overall, a significant increase in plasma membrane permeability (PMP), enzymatic antioxidants (EA), and nonenzymatic antioxidants (NEA) under water stress, but a decrease in plant growth and PS globally was observed, as shown in Table 2. An increase in ROS (by 65.7\%), MDA (by 44.2\%), and EL $(99.4 \%)$ shows malfunctioning of the plasma membrane and lipid peroxidation, thereby causing oxidative stress while decrease in chlorophyll (Chl) content (by 24\%), maximal efficiency of PSII photochemistry (Fv/Fm; by 13\%) and photochemical quenching coefficient ( $\mathrm{qP}$; by $26.4 \%$ ) indicates damage of photosynthetic organs and altered leaf structure under water stress conditions. An increase in EA (CAT, POD, and SOD) reveals the ability of the plants to manage water stress by maintaining normal metabolic processes. High NEA levels, especially ABA (+126\%), Pro (+136.8\%), and soluble sugar $(+116.9 \%)$ contents under water stress suggest the plant adaptation mechanisms in order to endure the adverse effect of ROS under water stress. Thus, this meta-analysis proved the negative impact of water stress on overall plant growth and performance.

Table 2. Plant morphology, physiology, and functionalities in response to drought, according to studies by Sun et al. [117].

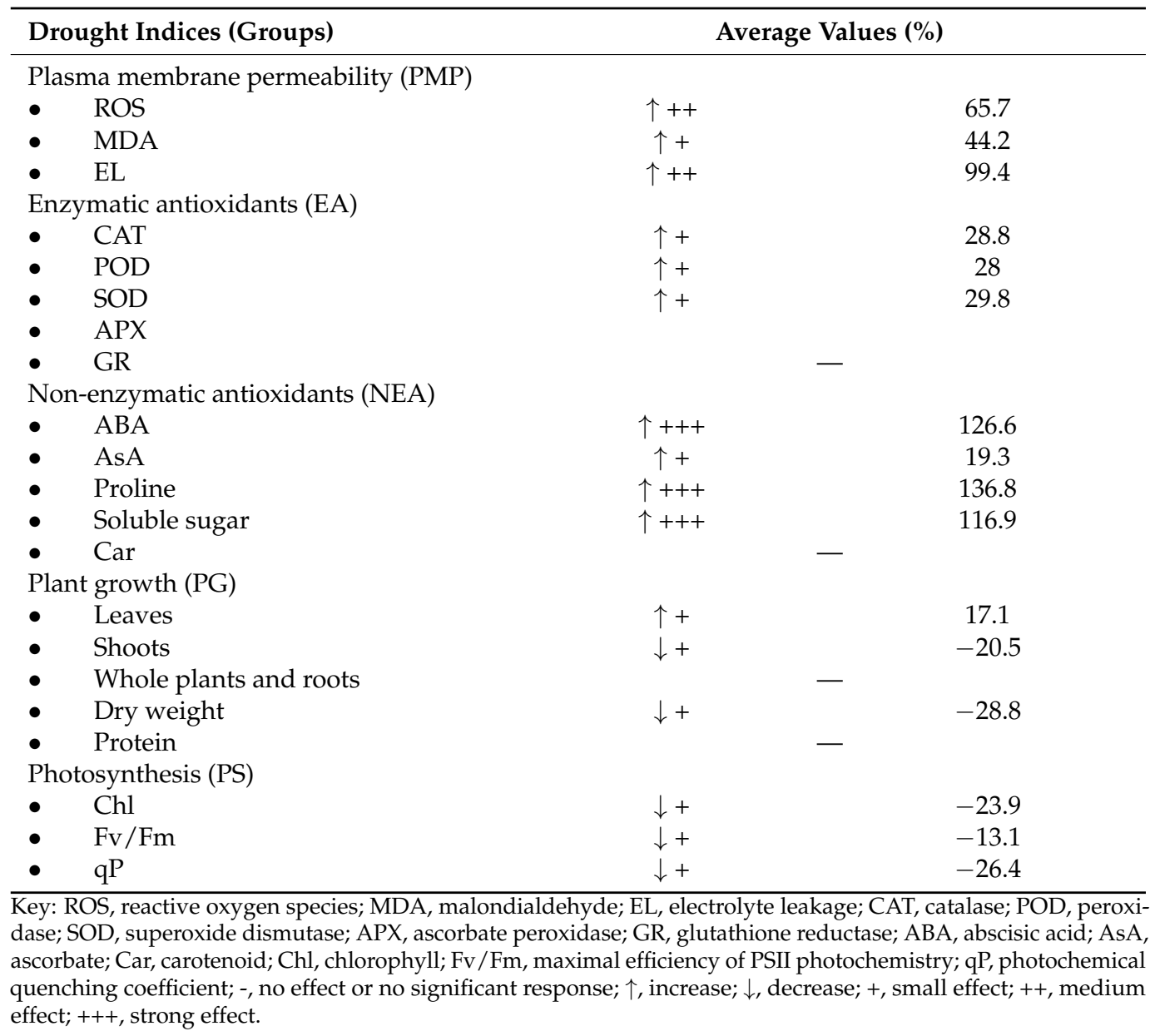




\subsection{Transcriptomic and Metabolomic Changes in Plants under Drought Stress}

Response of plants to water-deficient conditions can be observed at transcriptomic and metabolomic levels (Figure 2) [21,86,118]. You et al. [21] studied drought-tolerant (DT) and drought-susceptible (DS) sesame genotypes under drought stress and found that DS plants were more disturbed by stress conditions that was confirmed at both transcriptional and metabolic levels. Such plants contained more drought-responsive genes and metabolites when compared to DT genotype. Transcriptomic analyses of DT and DS sesame plants revealed the presence of a total 2782 and 3542 up-regulated and 4163 and 4519 downregulated genes, respectively. Among them, a set of core drought-responsive genes (a total 2030 genes including 648 up-regulated and 1346 down-regulated genes) that were differentially expressed in both sesame genotypes under drought conditions was found. Upregulated core drought-responsive genes were involved in protein processing in the endoplasmic reticulum, galactose metabolism, and plant hormone signal transduction, while down-regulated core drought-responsive genes in photosynthesis, fatty acid biosynthesis, sugar, and amino acid metabolism (amino sugar and nucleotide sugar metabolism, glycine, serine and threonine metabolism, phenylalanine, tyrosine and tryptophan biosynthesis), DNA replication, and ribosome pathways. Transcriptomic analyses of both genotypes showed that although they share common pathways to cope with drought stress, some unique ones, such as these related to alpha-Linolenic acid metabolism, valine, leucine, and isoleucine degradation, photosynthesis and peroxisome were recognized in DT sesame plants [21]. Many other transcriptomic and metabolomic analyses in plants under drought stress highlighted the important role of amino acid metabolism and ABA metabolism and signaling pathways for drought tolerance in plants [119-125].

The most important metabolites, which are accumulated in plants under drought stress include phytohormone $\mathrm{ABA}$, amino acids such as tryptophan, phenylalanine, valine, leucine, tyrosine, saccharopine, Pro and 2-aminoadipate, 4-aminobutanoic acid (GABA), and organic acids, namely glutaric acid, and 2-methylcitric acid. Accumulation of tryptohan is thought to play an important role in the regulation of stomata, osmotic adjustment, and ROS scavenging [126]. Especially, higher levels of ABA, Pro, arginine, lysine, aromatic and branched-chain amino acids, GABA, saccharopine, 2-aminoadipate, and allantoin were found in drought-tolerant sesame plants under drought conditions [21]. Similarly, droughttolerant chickpea plants showed a lower level of oxidative damage than their droughtsensitive counterparts and higher activity of POD, CAT, AsA, and GSH and accumulation of Pro and consequently lower production of $\mathrm{H}_{2} \mathrm{O}_{2}$ or MDA [20]. In contrast, some nucleosides and nucleotides such as guanosine, uridine, adenosine monophosphate, cytidine monophosphate, guanosine monophosphate, and uridine monophosphate), and sugars such as D-galactose and stachyose were reduced under drought stress in both DS and DT sesame genotypes [21].

In addition, other genes encoding for chaperones, including heat shock proteins (HSP) and small heat shock proteins (sHSP), Dna J proteins, aquaporins, orthologs of ABFs (ABA-Responsive-Element binding factors), and DREB2s (Dehydration-ResponsiveElement-Binding Proteins 2), glutaredoxins (GRXs), glutathione S-transferase (GST), and many more can also be involved in plant response to drought stress [127-136]. Transcriptome analysis of the many other plants or crops such as pine (Pinus massoniana) [137], tea oil camellia (Camellia oleifera) [138], maize (Zea mays L.) [139], peanut (Arachis hypogaea L. varieties) [140], endemic orchid species (Dendrobium sinense) [118] under drought stress also provided insights into the molecular mechanism such as expression of drought stress genes and certain functional genes that helps the plant to cope with drought stress. Tahmasebi et al. [141] investigated the transcriptional response of two different plant species (Oryza sativa (rice, $C_{3}$ plant) and Zea mays (maize, $C_{4}$ plant)) to drought stress based on 172 arrays in total from 11 drought stress studies. This meta-analysis also took into account the transcriptional response of shared differentially expressed genes (DEGs) in sorghum and barley, with respect to maize and rice, respectively, to drought stress, as shown in Table 3. In this meta-analysis, gene ontology (GO) analysis showed DEGs associated with photosynthesis, 
metabolic pathways, and stress response. In maize, genes encoding for cytochrome c oxidase protein (COX19-like), metabolic processes, osmotic stress, photosynthesis, antioxidant activity, DNA complex, defense signaling pathways, heat shock protein, photosynthetic gas exchange as well as other DEGs play an important role in drought tolerance. In rice, dehydrin protein (RAB16B) genes that are responsible for drought tolerance were highly upregulated, and also genes responsible for stress tolerance, plant transduction, photosynthesis, metabolic processes, oxidoreductase activity, and other DEGs, as mentioned in Table 4, were expressed. Several DEGs were identified under stress conditions in both plant species, as listed in Tables 3 and 4 . In both $C_{3}$ and $C_{4}$ plants, genes such as transcription factors, plastid translation, DNA replication and repair, antioxidant activity, and antioxidant defense genes were detected, as well as genes related to the hormone cytokinin, plant hormone signal transduction, and carbon fixation were differentially co-expressed between species under stress conditions. This study reflects on similarities and differences among the two plant species, such as the response to stress, small molecule metabolic process, response to cytokinin, and photosynthesis. Therefore, this meta-analysis indicated the influence of drought on the biological processes of both plants at a larger scale, thereby reflecting the importance of transcriptomic studies for obtaining precise information on plant response to drought stress.

Table 3. Meta-analysis on the transcriptional response of Sorghum and Barley to drought stress, according to a study by Tahmasebi et al. [141].

\begin{tabular}{lll}
\hline Variables & \multicolumn{1}{c}{ Sorghum } & \multicolumn{1}{c}{ Barley } \\
\hline Total DEGs & 300 genes (2\% orthologous with one of maize) & 2065 genes (7.2\% orthologous with one of rice) \\
\hline DEGs associated genes & $\begin{array}{l}\text { Alkaloid biosynthesis, plant hormone signal transduction, MAPK signalling pathway, response to } \\
\text { abiotic stimulus, and carbon metabolism. }\end{array}$ \\
\hline Transporter genes & $\begin{array}{l}\text { Transmembrane transporter activity genes-SPX } \\
\text { (Sb06g025950) and MS channel gene (Sb10g006710) }\end{array}$ & $\begin{array}{l}\text { ABC transporter system- Contig18416_at and } \\
\text { Contig13030_s_at }\end{array}$ \\
\hline Shared DEGs & With maize- ASR protein & With rice- biosynthesis of secondary metabolites \\
\hline & $\begin{array}{l}\text { Key: DEGs, differentially expressed genes; MAPK, mitogen-activated protein kinases; ABC, ATP-binding cassette; } \\
\text { ASR, abscisic acid- stress- ripening-induced. }\end{array}$
\end{tabular}

Table 4. Meta-analysis on the transcriptional response of Rice and Maize to drought stress, according to a study by Tahmasebi et al. [141].

\begin{tabular}{lcc}
\hline Variables & Maize & Rice \\
\hline Total DEGs & 4915 & 7291 \\
Upregulated genes & 2532 & 3491 \\
Downregulated genes & 2383 & 3800 \\
& Probesets related to Cox family, & \\
Highly upregulated identified DEGs & fasciclin-like arabinogalactan proteins & RAB16B and RAB21 genes \\
& Three genes encoding for Di19 & \\
Most highly downregulated identified DEGs & drought-induced 19 & PMEI-like and PEAMT2 genes \\
Stress tolerance genes & Histone H3-like proteins & LEA, HSP70, WSI76, and DREB1C \\
Predictive accuracy & Heat shock proteins & $98.72 \%$ \\
\hline
\end{tabular}

1. Gene Ontology Enrichment Analysis in

Each Species:

\section{DEGs}

Upregulated DEGs
Small molecule metabolic process Response to chemical Carbohydrate metabolic process Organic acid metabolic process

Response to osmotic stress
Plant hormone signal transduction

Response to temperature stimulus Response to salt stress Response to osmotic stress 
Table 4. Cont.

\begin{tabular}{|c|c|c|}
\hline Variables & Maize & Rice \\
\hline Downregulated DEGs & $\begin{array}{l}\text { Photosynthesis } \\
\text { Cofactor metabolic process }\end{array}$ & $\begin{array}{l}\text { Photosynthesis } \\
\text { Light reaction }\end{array}$ \\
\hline \multicolumn{3}{|l|}{ GO terms: } \\
\hline Biological processes & 47 DEGs & $\begin{array}{l}\text { Photosynthesis } \\
\text { Small molecule metabolic process } \\
\text { Oxidation-reduction process } \\
\text { Response to abiotic stimulus } \\
\text { 30 DEGs }\end{array}$ \\
\hline Species-specific enriched biological processes & $34 \%$ & $25 \%$ \\
\hline Molecular function & $\begin{array}{c}\text { Cation binding } \\
\text { Metal ion binding } \\
\text { Antioxidant activity } \\
\text { 8 DEGs }\end{array}$ & $\begin{array}{c}\text { Oxidoreductase activity } \\
\text { Catalytic activity } \\
\text { 8 DEGs }\end{array}$ \\
\hline Cellular component terms & $\begin{array}{l}\text { DNA packaging complex } \\
\text { Nucleosome } \\
\text { Thylakoid } \\
28 \text { DEGs }\end{array}$ & $\begin{array}{l}\text { Chloroplast } \\
\text { Plastid } \\
\text { 31 DEGs }\end{array}$ \\
\hline Common biological processes & \multicolumn{2}{|c|}{ Metabolic process and upregulated response to stress ( $41 \%$ common) } \\
\hline 2. Pathway Enrichment: & $\begin{array}{l}\text { Enriched with metabolic pathways } \\
\text { Carbon metabolism-related terms } \\
\text { Photosynthesis Biosynthesis of } \\
\text { secondary metabolites pathways }\end{array}$ & $\begin{array}{l}13 \text { KEGG pathways Downregulated } \\
\text { photosynthesis pathway Carbon } \\
\text { fixation in photosynthesis genes } \\
\text { Expression of hormone } \\
\text { signal transduction }\end{array}$ \\
\hline Upregulated metabolic pathways and genes & \multicolumn{2}{|c|}{$\begin{array}{l}\text { Asparagine synthetase, acyl-CoA oxidase and peroxidases, with } 1 \text { and } 9 \text { unique } \\
\text { pathways in maize and rice. }\end{array}$} \\
\hline
\end{tabular}

3. Identification of Consensus Modules:

Genes related to response to water

deprivation and small molecule $\quad$ BP-10, KEGG-5

metabolic process

$\begin{array}{ll}\text { Cell wall organization and cell cycle } & \text { BP- 18, KEGG-3 }\end{array}$

$\begin{array}{ll}\text { Photosynthesis } & \text { BP- } 6, \text { KEGG- } 6\end{array}$

Biogenesis and biosynthesis

BP- 6, KEGG- 2

4. Identification of Hub Genes:

Cell wall organization and cell cycle

Biogenesis and biosynthesis

Genes related to response to water deprivation

and small molecule metabolic process

Photosynthesis

5. Identification of Differential Co-expression

Modules:

Photosynthesis and response to cytokinin

Organic acid catabolic process

Response to stress

Cell wall organization

Alanine, aspartate, glutamate metabolism

(KEGG: 00250) enriched pathways

among genes

6. Co-localization of DEGs with

QTL Intervals:

DEGs localized within QTLs regions

Drought tolerance

Photosynthetic gas exchange

$\mathrm{d}^{13} \mathrm{C}$

Root characteristics traits
Mainly enriched in pyrimidine metabolism

FOR1 and PV72

PDHE1-A and HyPRP18

Protein of unknown function DUF676 and PDX1

Ankyrin-like protein and UBC37
MF- 5, BP- 8, KEGG- 3

MF- 2, BP- 17, KEGG- 6

MF- 2, BP- 9, KEGG- 1

MF- 8, BP- 30, KEGG- 3

MF- 1, KEGG- 1

$\begin{array}{cc}801 \mathrm{DEGs} & 1724 \mathrm{DEGs} \\ 141(2.8 \%) & 122(1.6 \%) \\ 444(10.5 \%) & 139(1.9 \%) \\ 59(1.2 \%) & 105(1.4 \%) \\ 157(3.19 \%) & 1358(18.6 \%)\end{array}$

Key: DEGs, differentially expressed genes; Cox, cytochrome c oxidase protein; Di19 drought-induced 19; BP biological process; KEGG, Kyoto Encyclopedia of Genes and Genomes; MF, molecular functions; $\mathrm{d}^{13} \mathrm{C}, \mathrm{C}$ isotope signature. 


\section{Plant Growth Promotion and Protection by PGPB and PGPF under Drought Conditions}

For the functioning of ecosystems, interactions between plants and soil microorganisms are of utmost importance, along with their response to climate changes [142,143]. Root exudates composed of enzymes, mucilage, ions, sugars, organic acids, amino acids, and so on actually decide the overall selection of root microbiome, as they attract beneficial bacteria. Changes in the composition of root exudates (e.g., presence of stress signals) during stressful conditions may significantly affect the root microbiome $[50,144]$, as discussed previously. Under drought conditions, mucilaginous material secreted by the roots becomes the major carbon nutrient source for microorganisms, thereby enhancing the nearby microbial biomass and altering the soil microbiome composition [145-147]. Therefore, efficient management and maintaining rhizospheric microorganisms are vital for the well-functioning of cropping practices [148]. Rhizosphere microbial communities adapt their structural and functional compositions to water scarcity and have the potential to substantially mitigate the drought stress of crops. Metagenomic analysis of the rhizobacterial communities revealed changes at the genome level in order to cope with drought stress. Such changes included enhancement of functional genes encoding for enzymes responsible for the breakdown of complex carbohydrates such as fructan and dextran, decrease in biofilm, and 1-aminocyclopropane-1-carboxylic acid (ACC) deaminase production, and reduction in genes encoding for spermidine $(\mathrm{R}, \mathrm{R})$-butanediol dehydrogenase and glutathione. [22]. The plant growth-promoting rhizobacteria (PGPR) and fungi (PGPF) by colonizing the root areas are known to contribute towards the plant adaptive mechanism in order to help the plant to survive the adverse effects of drought stress, as shown in Table 5. Microorganisms associated with plant roots minimize the harmful effects of stresses by delaying wilt and drought-induced changes (stomatal conductance, photosynthesis, and leaf discoloration), increasing amino acid content and Pro production, reducing $\mathrm{H}_{2} \mathrm{O}_{2}$ content, and increasing total phenolics in plants [1,149-153], increase nitrogen fixation, nutrients uptake, siderophore, phytohormone and secondary metabolite production, synthesis of exopolysaccharides (EPS), and many other organic compounds, and enhance enzyme activities [154-164], and many more (Table 5).

Table 5. Plant growth-promoting mechanisms by PGPR in drought stress conditions.

\begin{tabular}{|c|c|c|c|}
\hline Microorganisms & Plants & Protection/Effect/Mechanisms & References \\
\hline Azospirillum lipoferum & Maize (Zea mays. L) & $\begin{array}{l}\text { Improves growth of the plant, } \\
\text { increase in amino acid contents, } \\
\text { sugar accumulation, } \\
\text { and Pro production. }\end{array}$ & [165] \\
\hline Bacillus spp. & Maize (Zea mays. L) & $\begin{array}{l}\text { Improves intake of soluble sugar, } \\
\text { amino acids, and Pro reduces loss } \\
\text { of electrolytes and activity of } \\
\text { catalase and glutathione } \\
\text { PER enzymes. }\end{array}$ & [166] \\
\hline Pseudomonas putida strain GAP-P45 & $\begin{array}{l}\text { Sunflower (var. Sunbred } \\
\text { Helianthus annuus L.) }\end{array}$ & $\begin{array}{l}\text { Improved uptake of nutrients in } \\
\text { plant and increased growth of } \\
\text { the plant. }\end{array}$ & [167] \\
\hline Bacillus licheformis strain K11 & Pepper (Capsicum annum) & $\begin{array}{l}\text { Promotes growth of pepper, } \\
\text { produces ACC deaminase, and } \\
\text { prevents phytophthora blight. }\end{array}$ & [168] \\
\hline $\begin{array}{l}\text { Rhizobium tropici and Paenibacillus } \\
\text { polymyxa }\end{array}$ & Bean (Phaseolus vulgaris) & $\begin{array}{l}\text { Improved growth, nodulation, } \\
\text { and nitrogen content. }\end{array}$ & [169] \\
\hline
\end{tabular}


Table 5. Cont.

\begin{tabular}{|c|c|c|c|}
\hline Microorganisms & Plants & Protection/Effect/Mechanisms & References \\
\hline Sinorhizobium medicae & $\begin{array}{c}\text { Barrel medic (Medicago } \\
\text { truncatula) }\end{array}$ & $\begin{array}{l}\text { Delay in drought-induced leaf } \\
\text { senescence, increase in potassium, } \\
\text { drought-responsive proteins, and } \\
\text { osmolyte production. }\end{array}$ & {$[170]$} \\
\hline $\begin{array}{c}\text { Bacillus amyloliquefaciens } 5113 \text { and } \\
\text { Azospirillum brasilense NO40 }\end{array}$ & Wheat (Triticum aestivum L.) & $\begin{array}{l}\text { Improves plant growth, enhances } \\
\text { enzyme activities } \\
\text { (mono-dehydroascorbate } \\
\text { reductase (MDHAR), glutathione } \\
\text { reductase (GR), and } \\
\text { dehydroascorbate reductase } \\
\text { (DHAR) and APX), lower } \\
\text { antioxidant enzyme activities, and } \\
\text { increases photosynthesis. }\end{array}$ & {$[171]$} \\
\hline $\begin{array}{c}\text { Pseudomonas libanensis TR1 and } \\
\text { Pseudomonas reactans Ph3R3 }\end{array}$ & $\begin{array}{l}\text { Smooth-stem turnip (Brassica } \\
\text { oxyrrhina) }\end{array}$ & $\begin{array}{l}\text { Enhances plant growth, leaf } \\
\text { relative water content (RWC), } \\
\text { resistance to heavy metals and } \\
\text { antibiotics, increased chlorophyll } \\
\text { content, and decrease in } \\
\text { malondialdehyde content. }\end{array}$ & {$[172]$} \\
\hline Pseudomonas putida MTCC5279 (RA) & Chickpea (Cicer arietinum L.) & $\begin{array}{l}\text { Improves plant growth, nodule } \\
\text { formation, low antioxidant } \\
\text { enzymes, and increases } \\
\text { biochemical responses. }\end{array}$ & {$[173]$} \\
\hline Piriformospora indica & $\begin{array}{c}\text { Thale cress (Arabidopsis } \\
\text { thaliana) }\end{array}$ & Expression of stress-related genes. & {$[174]$} \\
\hline
\end{tabular}

Improved root colonization, nutrient or water holding capacity of the rhizosphere, Improved drought tolerance index of the wheat seedlings, enhanced the

Rhizobium leguminosarum (LR-30),

Mesorhizobium ciceri (CR-30 and CR39), Wheat (Triticum aestivum L.) and Rhizobium phaseoli (MR-2) root or shoot lengths and fresh or dry biomass of the seedlings, production of phytohormones (IAA), exopolysaccharides or catalase, osmolytes and antioxidants in the rhizosphere.
Azospirillum sp.

Trichoderma harzianum

Rice (Oryza sativa L.)
Plant growth enhancement.

Delay to wilt, drought-induced changes (stomatal conductance, photosynthesis, and leaf discoloration), promote plant growth, increase in Pro content, reduction in $\mathrm{H}_{2} \mathrm{O}_{2}$ content, and increase in total phenolics.
Improve height, fresh weight, and

the number of leaves of the walnut plant increased the Glomus etunicatum English walnut (Juglans regia) biosynthesis of some metabolites, including soluble sugar and Pro, total phenolic content, peroxidase activity, and starch content as well as peroxidase enzyme activity.

Enhancement of plant growth, fruit yield, drought tolerance and resistance to pathogens. 
Table 5. Cont.

\begin{tabular}{|c|c|c|c|}
\hline Microorganisms & Plants & Protection/Effect/Mechanisms & References \\
\hline $\begin{array}{l}\text { Glomus lamellosum and Glomus } \\
\text { etunicatum }\end{array}$ & $\begin{array}{c}\text { Cinnamon (Cinnamomum } \\
\text { migao) }\end{array}$ & $\begin{array}{l}\text { Improvement in seedling growth, } \\
\text { higher POD and CAT activity, } \\
\text { decrease in sugar and } \\
\text { osmoreceptor content, reduction } \\
\text { of accumulation of MDA, and } \\
\text { enhancement of } \\
\text { water-use efficiency in the plant. }\end{array}$ & {$[178]$} \\
\hline Alternaria sp. and Trichoderma harzianum & $\begin{array}{c}\text { Tomato (Solanum lycopersicum } \\
\text { var. Rutger) }\end{array}$ & $\begin{array}{l}\text { Improvement in root and shoot } \\
\text { biomass, enhancement of } \\
\text { water-use efficiency, and better } \\
\text { photosynthetic efficiency. }\end{array}$ & {$[179]$} \\
\hline
\end{tabular}

\section{Conclusions and Further Perspectives}

According to the recent studies $[6,10,11]$ and last reports of ICCP [2] and EEA, anthropogenic activities have significantly contributed towards climate change and drought that is the most important consequence of climate change in recent decades with a negative influence on our ecosystem, agriculture, and economy [6-10]. In this review article, we discussed various impacts of drought on soil microbial communities and plants. Although in previously published papers, the impact of drought on microbial community abundance, structure, and activity was described, our current knowledge is still incomplete. Soil is a very complex environment. Therefore, microbial community structure and its activity are not easy to explore and predict. The type of soil, especially the content of organic matter and the accompanying type of vegetation, is a very important aspect in determining changes in the structure and activity of soil microorganisms and subsequently enzyme activities, pools, fluxes, and carbon and nitrogen cycles. There are still relatively few metagenomic studies of microorganisms inhabiting drought-affected soil environments, and this scientific problem should be solved. Comprehensive analyses of microbial genome sequences, especially drought-tolerant ones, for genes encoding for drought stress-related compounds seem to be a promising tool to broaden our knowledge on how microorganisms cope with such harsh conditions. To date, synthesis of polysaccharides, xeroprotectants such as soluble sugars, proteins, and amino acids, as well as phytohormones (ABA, JA, ACC, IAA), and many more were described to increase microbial and plant resistance. An especially interesting solution to mitigate the negative effects of drought stress in the soil, mainly semiarid and arid ones, and improve microbial abundance, activity, and soil fertility by amendment of soil with various types of organic compounds, including compost, sewage sludge, and municipal solid waste [43]. In addition, the use of specific compounds such as plant hormones was also proposed [25]. However, the response of microorganisms to phytohormones is ambiguous and further research is required.

Plants respond to water scarcity in different ways, and this is a complex process that we still need to work on to unravel completely. In past studies, changes in plant morphology, anatomy, biochemistry, and physiology under drought stress were described in detail. However, plant response to such extreme conditions at the trancriptomic and metabolomic levels is still deficient. Therefore, more studies on the response of different plant species to drought stress are required to understand various adaptive mechanisms evolved in these organisms. In addition, meta-analysis studies seem to be a valuable approach to know global patterns of changes in the microbial community, its activity, and plants affected by stress conditions.

Based on the current knowledge, some improvement in crop management skills such as handling or selection of appropriate crops and soil, maintaining good levels of soil water content, insertion of abiotic stress tolerance traits into the plants using genetic engineering or genome editing technologies were proposed to increase plant productivity in such abiotic stress. Moreover, application of osmolytes, potassium, hydrogels, nanoparticles, mineral 
nutrient (silicon), antioxidative protectant (selenium), and plant growth regulators such as uniconazole and salicylic acid were considered to increase plant yield under abiotic stress $[1,73,129,180-183]$. In addition, the application of plant hormones such as ABA, gibberellic acid (GA), ethylene, auxins, JA, cytokinins, and brassinolide (BR) that regulate different beneficial mechanisms in the plants can help them to cope with the adverse effects of droughts [1,73]. A summarized outline of possible approaches for managing crop practices under drought stress is represented in Figure 3.

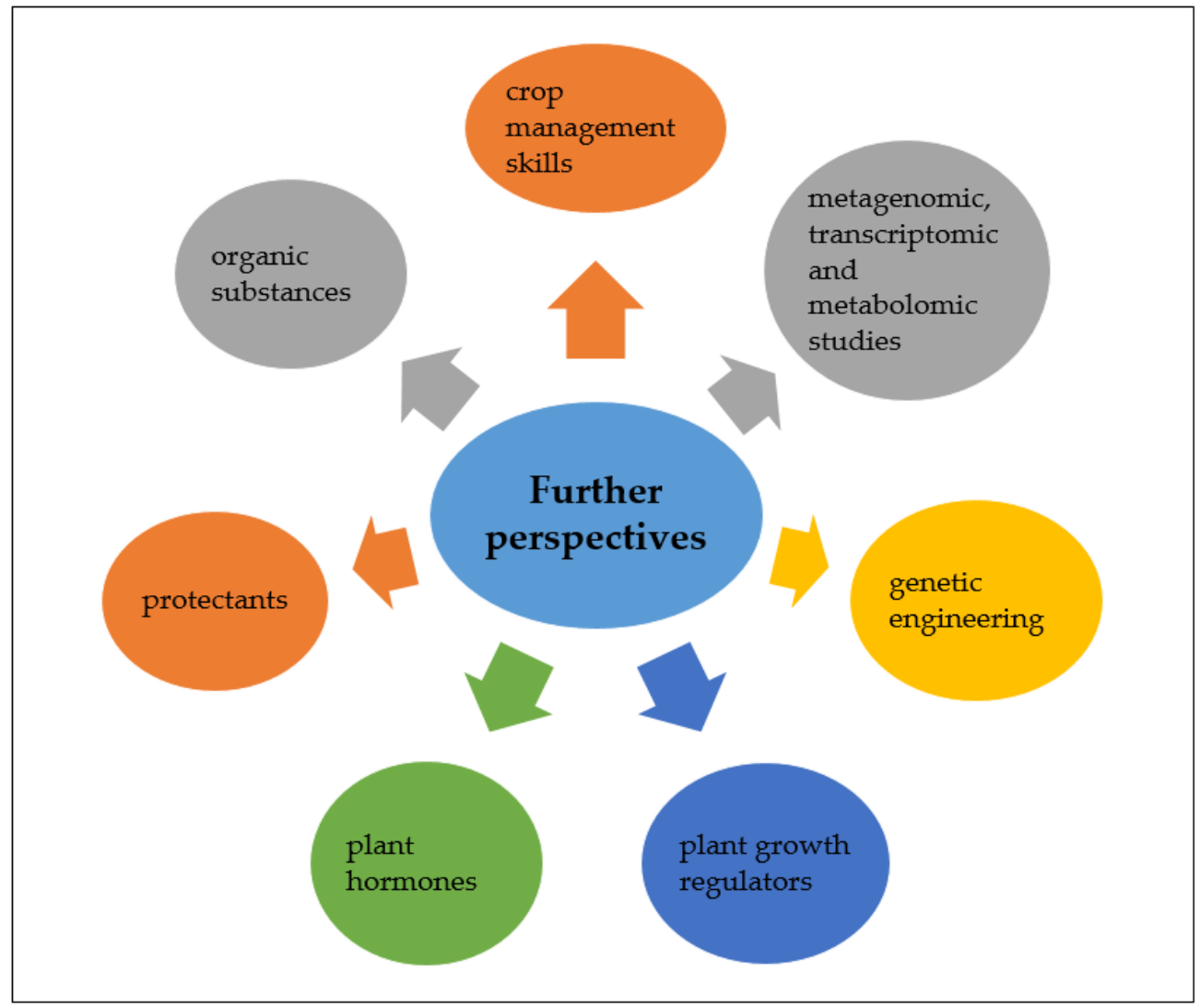

Figure 3. Future possible perspectives in order to mitigate drought stress.

Author Contributions: Conceptualization, M.W.; writing—original draft preparation, K.B.; writingreview and editing K.B. and M.W.; visualization, K.B.; supervision, M.W.; funding acquisition, K.B. All authors have read and agreed to the published version of the manuscript.

Funding: The APC was funded by Nicolaus Copernicus University.

Data Availability Statement: No new data were created or analyzed in this study. Data sharing is not applicable to this article.

Conflicts of Interest: The authors declare no conflict of interest. The funders had no role in the design of the study, in the collection, analyses, or interpretation of data and in the writing of the manuscript, or in the decision to publish the results.

\section{References}

1. Lamaoui, M.; Jemo, M.; Datla, R.; Bekkaoui, F. Heat and drought stresses in crops and approaches for their mitigation. Front. Chem. 2018, 6, 1-14. [CrossRef]

2. IPCC. Summary for Policymakers. In Climate Change 2021: The Physical Science Basis. Contribution of Working Group I to the Sixth Assessment Report of the Intergovernmental Panel on Climate Change; MassonDelmotte, V., Zhai, P., Pirani, A., Connors, S.L., Péan, C., Berger, S., Caud, N., Chen, Y., Goldfarb, L., Gomis, M.I., et al., Eds.; Cambridge University Press: Cambridge, UK, 2021; in press.

3. Kala, C.P. Environmental and socioeconomic impacts of drought in India: Lessons for drought management. Appl. Ecol. Environ. Res. 2017, 5, 43-48. 
4. Silva, E.C.D.; Albuquerque, M.B.D.; Neto, A.D.D.A.; Junior, C.D.D.S. Responses of Organisms to Water Stress. In Drought and Its Consequences to Plants- from Individual to Ecosystem, 1st ed.; Chapter 2; Akinci, S., Ed.; Şener Akınc1: London, UK, 2013 ; pp. 17-47.

5. Abdul Rahman, N.S.N.; Abdul Hamid, N.W.; Nadarajah, K. Effects of Abiotic Stress on Soil Microbiome. Int. J. Mol. Sci. 2021, $22,9036$. [PubMed]

6. Khan, R.; Gilani, H. Global drought monitoring with big geospatial datasets using Google Earth Engine. Environ. Sci. Pollut. Res. 2021, 28, 17244-17264. [CrossRef] [PubMed]

7. Epule, E.T.; Peng, C.; Lepage, L.; Chen, Z. The causes, effects and challenges of Sahelian droughts: A critical review. Reg. Environ. Chang. 2014, 14, 145-156. [CrossRef]

8. Wheaton, E.; Kulshreshtha, S.; Wittrock, V.; Koshida, G. Dry times: Hard lessons from the Canadian drought of 2001 and 2002. Can. Geograph. 2008, 52, 241-262. [CrossRef]

9. Gornall, J.; Betts, R.; Burke, E.; Clark, R.; Camp, J.; Willett, K.; Wiltshire, A. Implications of climate change for agricultural productivity in the early twenty-first century. Philos. Trans. R. Soc. B Biol. Sci. 2010, 365, 2973-2989. [CrossRef]

10. Lesk, C.; Rowhani, P.; Ramankutty, N. Influence of extreme weather disasters on global crop production. Nature 2016, 529, 84-87. [CrossRef]

11. Grillakis, M.G. Increase in severe and extreme soil moisture droughts for Europe under climate change. Sci. Total Environ. 2019, 660, 1245-1255. [CrossRef]

12. Siebielec, S.; Siebielec, G.; Klimkowicz-Pawlas, A.; Gałąka, A.; Grządziel, J.; Stuczyński, T. Impact of water stress on microbial community and activity in sandy and loamy soils. Agronomy 2020, 10, 1429. [CrossRef]

13. Ziernicka-Wojtaszek, A. Summer Drought in 2019 on Polish Territory-A Case Study. Atmosphere 2021, 12, 1475. [CrossRef]

14. Kränzlein, M.; Geilfus, C.M.; Franzisky, B.L.; Zhang, X.; Wimmer, M.A.; Zörb, C. Physiological responses of contrasting maize (Zea mays L.) hybrids to repeated drought. J. Plant Growth Regul. 2021, 1-11. [CrossRef]

15. Jamil, M.; Ahamd, M.; Anwar, F.; Zahir, Z.A.; Kharal, M.A.; Nazli, F. Inducing drought tolerance in wheat through combined use of L-tryptophan and Pseudomonas fluorescens. Pak. J. Agric. Sci. 2018, 55, 331-337.

16. Yin, B.; Wang, Y.; Liu, P.; Hu, J.; Zhen, W. Effects of vesicular-arbuscular mycorrhiza on the protective system in strawberry leaves under drought stress. Front. Agric. China 2010, 4, 165-169. [CrossRef]

17. Zapata, T.; Galindo, D.M.; Corrales-Ducuara, A.R.; Ocampo-Ibáñez, I.D. The diversity of culture-dependent gram-negative Rhizobacteria associated with Manihot esculenta crantz plants subjected to water-deficit stress. Diversity 2021, 13, 366. [CrossRef]

18. Nguyen, L.T.T.; Osanai, Y.; Anderson, I.C.; Bange, M.P.; Tissue, D.T.; Singh, B.K. Flooding and prolonged drought have dierential legacy impacts on soil nitrogen cycling, microbial communities and plant productivity. Plant. Soil 2018, 431, 371-387. [CrossRef]

19. Hanaka, A.; Ozimek, E.; Reszczy' nska, E.; Jaroszuk-'Sciseł, J.; Stolarz, M. Plant tolerance to drought stress in the presence of supporting bacteria and fungi: An efficient strategy in horticulture. Horticulturae 2021, 7, 390. [CrossRef]

20. Khan, M.N.; Zhang, J.; Luo, T.; Liu, J.; Ni, F.; Rizwan, M.; Fahad, S.; Hu, L. Morpho-physiological and biochemical responses of tolerant and sensitive rapeseed cultivars to drought stress during early seedling growth stage. Acta Physiol. Plant 2019, 41, 25 [CrossRef]

21. You, J.; Zhang, Y.; Liu, A.; Li, D.; Wang, X.; Dossa, K.; Zhou, R.; Yu, J.; Zhang, Y.; Wang, L.; et al. Transcriptomic and metabolomic profiling of drought-tolerant and susceptible sesame genotypes in response to drought stress. BMC Plant Biol. 2019, 19, 267. [CrossRef]

22. Breitkreuz, C.; Herzig, L.; Buscot, F.; Reitz, T.; Tarkka, M. Interactions between soil properties, agricultural management and cultivar type drive structural and functional adaptations of the wheat rhizosphere microbiome to drought. Environ. Microbiol. 2021, 23, 5866-5882. [CrossRef] [PubMed]

23. Milošević, N.A.; Marinković, J.B.; Tintor, B.B. Mitigating abiotic stress in crop plants by microorganisms. Proc. Nat. Sci. Matica Serpska Novi. Sad 2012, 123, 17-26. [CrossRef]

24. Pascual, J.A.; Hernandez, T.; Garcia, C.; Ayuso, M. Enzymatic activities in an arid soil amended with urban organic wastes: Laboratory experiment. Bioresour. Technol. 1998, 64, 131-138. [CrossRef]

25. Sayer, E.J.; Crawford, J.A.; Edgerley, J.; Askew, A.P.; Hahn, C.Z.; Whitlock, R.; Dodd, I.C. Adaptation to chronic drought modifies soil microbial community responses to phytohormones. Commun. Biol. 2021, 4, 516. [CrossRef]

26. Schimel, J.; Balser, T.C.; Wallenstein, M. Microbial stress-response physiology and its implications for ecosystem function. Ecology 2007, 88, 1386-1394. [CrossRef]

27. Yerbury, J.J.; Stewart, E.M.; Wyatt, A.R.; Wilson, M.R. Quality control of protein folding in extracellular space. EMBO Rep. 2005, 6, 1131-1136. [CrossRef] [PubMed]

28. Csonka, L.N. Physiological and genetic responses of bacteria to osmotic stress. Microbiol. Rev. 1989, 53, 121-147. [CrossRef]

29. LeBlanc, J.C.; Gonçalves, E.R.; Mohn, W.W. Global response to desiccation stress in the soil actinomycete Rhodococcus jostii RHA1. Appl. Environ. Microbiol. 2008, 74, 2627-2636. [CrossRef]

30. Narváez-Reinaldo, J.J.; Barba, I.; González-López, J.; Tunnacliffe, A.; Manzanera, M. Rapid method for isolation of desiccationtolerant strains and xeroprotectants. Appl. Environ. Microbiol. 2010, 76, 5254-5262. [CrossRef]

31. Alvarez, H.M.; Silva, R.A.; Cesari, A.C.; Zamit, A.L.; Peressutti, S.R.; Reichelt, R.; Keller, U.; Malkus, U.; Rasch, C.; Maskow, T.; et al. Physiological and morphological responses of the soil bacterium Rhodococcus opacus strain PD630 to water stress. FEMS Microbiol. Ecol. 2004, 50, 75-86. [CrossRef] 
32. Palud, A.; Salem, K.; Cavin, J.F.; Beney, L.; Licandro, H. Identification and transcriptional profile of Lactobacillus paracasei genes involved in the response to desiccation and rehydration. Food Microbiol. 2020, 85, 103301. [CrossRef] [PubMed]

33. Vílchez, J.I.; García-Fontana, C.; Román-Naranjo, D.; González-López, J.; Manzanera, M. Plant drought tolerance enhancement by trehalose production of desiccation-tolerant microorganisms. Front. Microbiol. 2016, 7, 1577. [CrossRef] [PubMed]

34. Manzanera, M. Dealing with water stress and microbial preservation. Environ. Microbiol. 2021, 23, 3351-3359. [CrossRef]

35. Vílchez, J.I.; Niehaus, K.; Dowling, D.N.; González-López, J.; Manzanera, M. Protection of pepper plants from drought by Microbacterium sp. 3J1 by modulation of the plant's glutamine and $\alpha$-ketoglutarate content: A comparative metabolomics approach. Front. Microbiol. 2018, 9, 284. [CrossRef] [PubMed]

36. Tanne, C.; Golovina, E.A.; Hoekstra, F.A.; Meffert, A.; Galinski, E.A. Glass-forming property of hydroxyectoine is the cause of its superior function as a desiccation protectant. Front. Microbiol. 2014, 5, 150. [CrossRef] [PubMed]

37. Julca, I.; Alaminos, M.; González-López, J.; Manzanera, M. Xeroprotectants for the stabilization of biomaterials. Biotechnol. Adv. 2012, 30, 1641-1654. [CrossRef] [PubMed]

38. SantaCruz-Calvo, L.; González-López, J.; Manzanera, M. Arthrobacter siccitolerans sp. nov., a highly desiccation-tolerant, xeroprotectant-producing strain isolated from dry soil. Int. J. Syst. Evol. Microbiol. 2013, 63, 4174-4180. [CrossRef] [PubMed]

39. Da Costa, M.S.; Santos, H.; Galinski, E.A. An overview of the role and diversity of compatible solutes in Bacteria and Archaea Adv. Biochem. Eng. Biotechnol. 1998, 61, 117-153. [PubMed]

40. Crisp, A.; Boschetti, C.; Perry, M.; Tunnacliffe, A.; Micklem, G. Expression of multiple horizontally acquired genes is a hallmark of both vertebrate and invertebrate genomes. Genome Biol. 2015, 16, 50. [CrossRef]

41. García-Fontana, C.; Narváez-Reinaldo, J.J.; Castillo, F.; González-López, J.; Luque, I.; Manzanera, M.A. New physiological role for the DNA molecule as a protector against drying Stress in desiccation-tolerant microorganisms. Front. Microbiol. 2016, 7, 2066. [CrossRef]

42. Arzanesh, M.H.; Alikhani, H.A.; Khavazi, K.; Rahimian, H.A.; Miransari, M. Wheat (Triticum aestivum L.) growth enhancement by Azospirillum sp. under drought stress. World J. Microbiol. Biotechnol. 2011, 27, 197-205. [CrossRef]

43. Hueso, S.; García, C.; Hernández, T. Severe drought conditions modify the microbial community structure, size and activity in amended and unamended soils. Soil Biol. Biochem. 2012, 50, 167-173. [CrossRef]

44. Baldrian, P.; Merhautová, V.; Petránková, M.; Cajthaml, T.; Šnajdr, J. Distribution of microbial biomass and activity of extracellular enzymes in a hardwood forest soil reflect soil moisture content. Appl. Soil Ecol. 2010, 46, 177-182. [CrossRef]

45. Bastida, F.; Torres, I.F.; Hernández, T.; García, C. The impacts of organic amendments: Do they confer stability against drought on the soil microbial community? Soil Biol. Biochem. 2017, 113, 173-183. [CrossRef]

46. Veach, A.M.; Zeglin, L.H. Historical drought affects microbial population dynamics and activity during soil drying and re-wet. Microb. Ecol. 2020, 79, 662-674. [CrossRef]

47. Castro, S.P.; Cleland, E.E.; Wagner, R.; Sawad, R.A.; Lipson, D.A. Soil microbial responses to drought and exotic plants shift carbon metabolism. ISME J. 2019, 13, 1776. [CrossRef] [PubMed]

48. Schimel, J.P. Life in dry soils: Effects of drought on soil microbial communities and processes. Annu. Rev. Ecol. Evol. 2018, 49, 409-432. [CrossRef]

49. Yuste, J.C.; Penuelas, J.; Estiarte, M.; Garcia-mas, J.; Mattana, S.; Ogaya, R.; Pujol, M.; Sardans, J. Drought-resistant fungi control soil organic matter decomposition and its response to temperature. Glob. Chang. Biol. 2011, 17, 1475-1486. [CrossRef]

50. Naylor, D.; DeGraaf, S.; Purdom, E.; Coleman-Derr, D. Drought and host selection influence bacterial community dynamics in the grass root microbiome. ISME J. 2017, 11, 2691-2704. [CrossRef]

51. Chernysheva, E.; Korobov, D.; Khomutova, T.; Fornasier, F.; Borisov, A. Soil microbiological properties in livestock corrals: An additional new line of evidence to identify livestock dung. J. Archaeol. Sci. Rep. 2021, 37, 103012. [CrossRef]

52. Kompała-Baba, A.; Bierza, W.; Sierka, E.; Błońska, A.; Besenyei, L.; Woźniak, G. The role of plants and soil properties in the enzyme activities of substrates on hard coal mine spoil heaps. Sci. Rep. 2021, 11, 5155. [CrossRef]

53. Meena, A.; Rao, K.S. Assessment of soil microbial and enzyme activity in the rhizosphere zone under different land use/cover of a semiarid region, India. Ecol. Process. 2021, 10, 1-12. [CrossRef]

54. Shukla, G.; Varma, A. (Eds.) Soil Enzymology; Springer: Berlin/Heidelberg, Germany, 2011; pp. 1-392.

55. Hemkemeyer, M.; Schwalb, S.A.; Heinze, S.; Joergensen, R.G.; Wichern, F. Functions of elements in soil microorganisms. Microb. Res. 2021, 252, 126832. [CrossRef] [PubMed]

56. Mulvaney, R.L.; Bremner, J.M. Use of p-benzoquinone and hydroquinone for retardation of urea hydrolysis in soils. Soil Biol. Biochem. 1978, 10, 297-302. [CrossRef]

57. Hu, J.; Lin, X.; Wang, J.; Dai, J.; Chen, R.; Zhang, J.; Wong, M.H. Microbial functional diversity, metabolic quotient, and invertase activity of a sandy loam soil as affected by long-term application of organic amendment and mineral fertilizer. J. Soils Sediments 2011, 11, 271-280. [CrossRef]

58. Bakshi, M.; Varma, A. Soil Enzyme: The State-of-Art. In Soil Enzymology; Shukla, G., Varma, A., Eds.; Springer: Berlin/Heidelberg, Germany, 2011; Volume 22, pp. 1-23.

59. Sardans, J.; Peñuelas, J. Drought decreases soil enzyme activity in a Mediterranean Quercus ilex L. forest. Soil Biol. Biochem. 2005, 37, 455-461. [CrossRef]

60. Bååth, E.; Söderström, B. Seasonal and spatial variation in fungal biomass in a forest soil. Soil Biol. Biochem. 1982, 14, 353-358. [CrossRef] 
61. Larned, S.T.; Datry, T.; Robinson, C. Invertebrate and microbial responses to inundation in an ephemeral river reach in New Zealand: Effects of preceding dry periods. Aquat. Sci. 2007, 69, 554-567. [CrossRef]

62. Pohlon, E.; Fandino, A.O.; Marxsen, J. Bacterial community composition and extracellular enzyme activity in temperate streambed sediment during drying and rewetting. PLoS ONE 2013, 8, e83365. [CrossRef] [PubMed]

63. Schreckinger, J.; Mutz, M.; Mendoza-Lera, C.; Frossard, A. Attributes of drying define the structure and functioning of microbial communities in temperate riverbed sediment. Front. Microbiol. 2021, 12, 676615. [CrossRef]

64. Sirová, D.; Vrba, J.; Rejmánková, E. Extracellular enzyme activities in benthic cyanobacterial mats: Comparison between nutrient-enriched and control sites in marshes of northern Belize. Aquat. Microb. Ecol. 2006, 44, 11-20. [CrossRef]

65. Criquet, S.; Farnet, A.M.; Tagger, S.; Le Petit, J. Annual variations of phenoloxidase activities in an evergreen oak litter: Influence of certain biotic and abiotic factors. Soil Biol. Biochem. 2000, 32, 1505-1513. [CrossRef]

66. Criquet, S.; Ferre, E.; Farnet, A.M.; Le petit, J. Annual dynamics of phosphatase activities in an evergreen oak litter: Influence of biotic and abiotic factors. Soil Biol. Biochem. 2004, 36, 1111-1118. [CrossRef]

67. Siebielec, G.; Siebielec, S.; Lipski, D. Long-term impact of sewage sludge, digestate and mineral fertilizers on plant yield and soil biological activity. J. Clean. Prod. 2018, 187, 372-379. [CrossRef]

68. Weintraub, M.N.; Scott-Denton, L.E.; Schmidt, S.K.; Monson, R.K. The effects of tree rhizodeposition on soil exoenzyme activity, dissolved organic carbon, and nutrient availability in a subalpine forest ecosystem. Oecologia 2007, 154, 327-338. [CrossRef] [PubMed]

69. Preece, C.; Verbruggen, E.; Liu, L.; Weedon, J.T.; Peñuelas, J. Effects of past and current drought on the composition and diversity of soil microbial communities. Soil Biol. Biochem. 2019, 131, 28-39. [CrossRef]

70. Gleeson, D.B.; Herrmann, A.M.; Livesley, S.J.; Murphy, D.V. Influence of water potential on nitrification and structure of nitrifying bacterial communities in semiarid soils. Appl. Soil Ecol. 2008, 40, 189-194. [CrossRef]

71. Fuchslueger, L.; Kastl, E.M.; Bauer, F.; Kienzl, S.; Hasibeder, R.; Ladreiter-Knauss, T.; Schmidt, M.; Bahn, M.; Schloter, M.; Richter, A.; et al. Effect of drought on nitrogen turnover and abundances of ammonia-oxidizers in mountain grassland. Biogeosciences 2014, 11, 6003-6015. [CrossRef]

72. Deng, L.; Peng, C.; Kim, D.G.; Li, J.; Liu, Y.; Hai, X.; Liu, Q.; Huang, C.; Shangguan, Z.; Kuzyakov, Y. Drought effects on soil carbon and nitrogen dynamics in global natural ecosystems. Earth Sci. Rev. 2021, 214, 103501. [CrossRef]

73. Hewedy, O.A.; Abdel Lateif, K.S.; Seleiman, M.F.; Shami, A.; Albarakaty, F.M.; El-Meihy, R.M. Phylogenetic diversity of Trichoderma strains and their antagonistic potential against soil-borne pathogens under stress conditions. Biology 2020, 9, 189. [CrossRef]

74. Wang, W.X.; Vinocur, B.; Shoseyov, O.; Altman, A. Biotechnology of plant osmotic stress tolerance: Physiological and molecular considerations. Acta Hortic. 2001, 560, 285-292. [CrossRef]

75. Wilmowicz, E.; Kućko, A.; Golińska, P.; Burchardt, S.; Przywieczerski, T.; Świdziński, M.; Brzozowska, P.; Kapuścińska, D. Abscisic acid and ethylene in the control of nodule-specific response on drought in yellow lupine. Environ. Exp. Bot. 2020, 169, 103900. [CrossRef]

76. Ulrich, D.E.M.; Sevanto, S.; Ryan, M.; Albright, M.B.N.; Johansen, R.B.; Dunbar, J.M. Plant-microbe interactions before drought influence plant physiological responses to subsequent severe drought. Sci. Rep. 2019, 9, 249. [CrossRef]

77. Jabbari, H.; Akbari, G.A.; Sima, N.A.K.K.; Rad, A.H.S.; Alahdadi, I.; Hamed, A.; Shariatpanahi, M.E. Relationships between seedling establishment and soil moisture content for winter and spring rapeseed genotypes. Ind. Crops Prod. 2013, 49, 177-187. [CrossRef]

78. Yang, X.; Lu, M.; Wang, Y.; Wang, Y.; Liu, Z.; Chen, S. Response Mechanism of Plants to Drought Stress. Horticulturae 2021, 7, 50. [CrossRef]

79. Sangtarash, M.H.; Qaderi, M.M.; Chinnappa, C.C.; Reid, D.M. Differential sensitivity of canola (Brassica napus L.) seedlings to ultraviolet-B radiation, water stress and abscisic acid. Environ. Exp. Bot. 2009, 66, 212-219. [CrossRef]

80. Qaderi, M.M.; Kurepin, L.V.; Reid, D.M. Effects of temperature and watering regime on growth gas exchange and abscisic acid content of canola (Brassica napus L.) seedlings. Environ. Exp. Bot. 2012, 75, 107-113. [CrossRef]

81. Liu, D.; Wu, L.; Naeem, M.S.; Liu, H.; Deng, X.; Xu, L.; Zhang, F.; Zhou, W. 5-Aminolevulinic acid enhances photosynthetic gas exchange, chlorophyll fluorescence and antioxidant system in oilseed rape under drought stress. Acta Physiol. Plant 2013, 35, 2747-2759. [CrossRef]

82. Chartzoulakis, K.; Patakas, A.; Kofidis, G.; Bosabalidis, A.; Nastou, A. Water stress affects leaf anatomy, gas exchange, water relations and growth of two avocado cultivars. Sci. Hortic. 2002, 95, 39-50. [CrossRef]

83. Furlan, A.; Llanes, A.; Luna, V.; Castro, S. Physiological and biochemical responses to drought stress and subsequent rehydration in the symbiotic association peanut-Bradyrhizobium sp. ISRN Agron. 2012, 2012, 890-895. [CrossRef]

84. Cutler, S.R.; Rodriguez, P.L.; Finkelstein, R.R.; Abrams, S.R. Abscisic acid: Emergence of a core signaling network. Annu. Rev. Plant Biol. 2010, 61, 651-679. [CrossRef] [PubMed]

85. Calvo, O.C.; Franzaring, J.; Schmid, I.; Müller, M.; Brohon, N.; Fangmeier, A. Atmospheric $\mathrm{CO}_{2}$ enrichment and drought stress modify root exudation of barley. Glob. Chang. Biol. 2016, 23, 1292-1304. [CrossRef] [PubMed]

86. Galeano, E.; Vasconcelos, T.S.; Novais de Oliveira, P.N.; Carrer, H. Physiological and molecular responses to drought stress in teak (Tectona grandis L.f.). PLoS ONE 2019, 14, e0221571. [CrossRef]

87. Takahashi, F.; Kuromori, T.; Urano, K.; Yamaguchi-Shinozaki, K.; Shinozaki, K. Drought stress responses and resistance in plants: From cellular responses to long-distance intercellular communication. Front. Plant Sci. 2020, 11, 556972. [CrossRef] [PubMed] 
88. Gimenez, C.; Mitchell, V.J.; Lawlor, D.W. Regulation of photosynthetic rate of two sunflower hybrids under water stress. Plant Physiol. 1992, 98, 516-524. [CrossRef] [PubMed]

89. Ma, P.; Bai, T.H.; Ma, F.W. Effects of progressive drought on photosynthesis and partitioning of absorbed light in apple trees. J. Integr. Agric. 2015, 14, 681-690. [CrossRef]

90. Reddy, A.R.; Chaitanya, K.V.; Vivekanandan, M. Drought-induced responses of photosynthesis and antioxidant metabolism in higher plants. J. Plant Physiol. 2004, 161, 1189-1202. [CrossRef]

91. Feng, Y.L.; Cao, K.F. Photosynthesis and photo inhibition after night chilling in seedlings of two tropical tree species grown under three irradiances. Photosynthetica 2005, 43, 567-574. [CrossRef]

92. Azzeme, A.M.; Abdullah, S.N.A.; Aziz, M.A.; Wahab, P.E.M. Oil palm leaves and roots differ in physiological response, antioxidant enzyme activities and expression of stress-responsive genes upon exposure to drought stress. Acta Physiol. Plant. 2016, 38, 1-12. [CrossRef]

93. Sabra, A.; Daayf, F.; Renault, S. Differential physiological and biochemical responses of three Echinacea species to salinity stress. Scientia. Hort. 2012, 135, 23-31. [CrossRef]

94. Tarazona, P.; Feussner, K.; Feussner, I. An enhanced plant lipidomics method based on multiplexed liquid chromatography-mass spectrometry reveals additional insights into cold- and drought-induced membrane remodeling. Plant J. $2015,84,621-633$. [CrossRef]

95. Dossa, K.; Li, D.; Wang, L.; Zheng, X.; Liu, A.; Yu, J.; Wei, X.; Zhou, R.; Fonceka, D.; Diouf, D.; et al. Transcriptomic, biochemical and physio-anatomical investigations shed more light on responses to drought stress in two contrasting sesame genotypes. Sci. Rep. 2017, 7, 8755. [CrossRef]

96. Bao, G.; Tang, W.; An, Q.; Liu, Y.; Tian, J.; Zhao, N.; Zhu, S. Physiological effects of the combined stresses of freezing-thawing, acid precipitation and deicing salt on alfalfa seedlings. BMC Plant Biol. 2020, 20, 204. [CrossRef]

97. Gupta, N.; Thind, S.K.; Bains, N.S. Glycine betaine application modifies biochemical attributes of osmotic adjustment in drought stressed wheat. Plant Growth Regul. 2014, 72, 221-228. [CrossRef]

98. Abdi, G.; Shokrpour, M.; Karami, L.; Salami, S.A. Prolonged water deficit stress and methyl jasmonate-mediated changes in metabolite profile, flavonoid concentrations and antioxidant activity in peppermint (Mentha $\times$ piperita L.). Not. Bot. Horti. Agrobo. 2019, 47, 70-80. [CrossRef]

99. Hou, P.; Wang, F.; Luo, B.; Li, A.; Wang, C.; Shabala, L.; Ahmed, H.A.I.; Deng, S.; Zhang, H.; Song, P.; et al. Antioxidant enzymatic activity and osmotic adjustment as components of the drought tolerance mechanism in Carex duriuscula. Plants $2021,10,436$. [CrossRef] [PubMed]

100. Ozturk, M.; Unal, B.T.; García-Caparrós, P.; Khursheed, A.; Gul, A.; Hasanuzzaman, M. Osmoregulation and its actions during the drought stress in plants. Physiol. Plant. 2021, 172, 1321-1335. [CrossRef] [PubMed]

101. Khoyerdi, F.F.; Shamshiri, M.H.; Estaji, A. Changes in some physiological and osmotic parameters of several pistachio genotypes under drought stress. Sci. Hortic. 2016, 198, 44-51. [CrossRef]

102. Liu, C.; Wang, Y.; Pan, K.; Li, W.; Zhang, L.; Shen, X.; Liu, L.; Deng, M. Responses of antioxidant defense system to drought stress in the leaves of Fargesia denudata seedlings, the staple food on the giant panda. Russ. J. Plant Physiol. 2014, 3, 374-383. [CrossRef]

103. Moral, A.Z.; Martínez-Reyes, D.; Quinto, C.; Sanchez, F.; Díaz-Camino, C. Identification of small open reading frames (sORFs) associated with heat tolerance in nitrogen-fixing root nodules of Phaseolus vulgaris wild-type and cv BAT93. Aust. J. Crop Sci. 2021, 15, 28-37. [CrossRef]

104. Ni, Z.; Liu, N.; Yu, Y.; Bi, C.; Chen, Q.; Qu, Y. The cotton 70-kDa heat shock protein GhHSP70-26 plays a positive role in the drought stress response. Environ. Exp. Bot. 2021, 191, 104628. [CrossRef]

105. Feng, X.H.; Zhang, H.X.; Ali, M.; Gai, W.X.; Cheng, G.X.; Yu, Q.H.; Yang, S.B.; Li, X.X.; Gong, Z.H. A small heat shock protein CaHsp25. 9 positively regulates heat, salt, and drought stress tolerance in pepper (Capsicum annuum L.). Plant Physiol. Biochem. 2019, 142, 151-162. [CrossRef] [PubMed]

106. Ma, X.L.; Wang, Y.J.; Xie, S.L.; Wang, C.; Wang, W. Glycinebetaine application ameliorates negative effects of drought stress in tobacco. Russ. J. Plant Physiol. 2007, 54, 472. [CrossRef]

107. Mignolet-Spruyt, L.; Xu, E.; Idänheimo, N.; Hoeberichts, F.A.; Mühlenbock, P.; Brosché, M.; Van Breusegem, F.; Kangasjärvi, J. Spreading the news: Subcellular and organellar reactive oxygen species production and signalling. J. Exp. Bot. 2016, 67, 3831-3844. [CrossRef]

108. Dietz, K.-J. Thiol-based peroxidases and ascorbate peroxidases: Why plants rely on multiple peroxidase systems in the photosynthesizing chloroplast? Mol. Cells 2016, 39, 20-25. [PubMed]

109. Dröse, S.; Brandt, U. Molecular mechanisms of superoxide production by the mitochondrial respiratory chain. Adv. Exp. Med. Biol. 2012, 748, 145-169.

110. Pacher, P.; Beckman, J.S.; Liaudet, L. Nitric Oxide and Peroxynitrite in Health and Disease. Physiol. Rev. 2007, 87, 315-424. [CrossRef]

111. Stadtman, E.R.; Moskovitz, J.; Levine, R.L. Oxidation of methionine residues of proteins: Biological consequences. Antioxid Redox Signal. 2003, 5, 577-582. [CrossRef]

112. Marnett, L.J. Oxyradicals and DNA damage. Carcinogenesis 2000, 21, 361-370. [CrossRef]

113. Apel, K.H.; Hirt, H. Reactive oxygen species: Metabolism, oxidative stress, and signal transduction. Annu. Rev. Plant Biol. 2004, 55, 373-399. [CrossRef] 
114. Kaur, K.; Kaur, N.; Gupta, A.K.; Singh, I. Exploration of the antioxidative defense system to characterize chickpea genotypes showing differential response towards water deficit conditions. Plant Growth Regul. 2013, 70, 49-60. [CrossRef]

115. Wang, W.B.; Kim, Y.H.; Lee, H.S.; Kim, K.Y.; Deng, X.P.; Kwak, S.S. Analysis of antioxidant enzyme activity during germination of alfalfa under salt and drought stresses. Plant Physiol. Biochem. 2009, 47, 570-577. [CrossRef]

116. Kuźniak, E.K.; Skłodowska, M. Ascorbate, glutathione and related enzymes in chloroplasts of tomato leaves infected by Botrytis cinerea. Plant Sci. 2001, 160, 723-731. [CrossRef]

117. Sun, Y.; Wang, C.; Chen, H.Y.H.; Ruan, H. Response of Plants to Water Stress: A Meta-Analysis. Front. Plant Sci. 2020, 11, 978. [CrossRef] [PubMed]

118. Zhang, C.; Chen, J.; Huang, W.; Song, X.; Niu, J. Transcriptomics and metabolomics reveal purine and phenylpropanoid metabolism response to drought stress in Dendrobium sinense, an endemic orchid species in Hainan Island. Front. Genet. 2021, 12, 692702. [CrossRef] [PubMed]

119. Zhu, J.K. Abiotic stress signaling and responses in plants. Cell 2016, 167, 313-324. [CrossRef]

120. Jaiswal, S.; Antala, T.J.; Mandavia, M.K.; Chopra, M.; Jasrotia, R.S.; Tomar, R.S.; Kheni, J.; Angadi, U.B.; Iquebal, M.A.; Golakia, B.A.; et al. Transcriptomic signature of drought response in pearl millet (Pennisetum glaucum L.) and development of web-genomic resources. Sci. Rep. 2018, 8, 3382. [CrossRef]

121. Egea, I.; Albaladejo, I.; Meco, V.; Morales, B.; Sevilla, A.; Bolarin, M.C.; Flores, F.B. The drought-tolerant Solanum pennellii regulates leaf water loss and induces genes involved in amino acid and ethylene/jasmonate metabolism under dehydration. Sci. Rep. 2018, 8, 2791. [CrossRef]

122. You, J.; Wang, Y.; Zhang, Y.; Dossa, K.; Li, D.; Zhou, R.; Wang, L.; Zhang, X. Genome-wide identification and expression analyses of genes involved in raffinose accumulation in sesame. Sci. Rep. 2018, 8, 4331. [CrossRef] [PubMed]

123. Wang, P.; Yang, C.; Chen, H.; Song, C.; Zhang, X.; Wang, D. Transcriptomic basis for drought-resistance in Brassica napus L. Sci. Rep. 2017, 7, 40532. [CrossRef]

124. Pires, M.V.; Júnior, A.A.P.; Medeiros, D.B.; Daloso, D.M.; Pham, P.A.; Barros, K.A.; Engqvist, M.K.; Florian, A.; Krahnert, I.; Maurino, V.G.; et al. The influence of alternative pathways of respiration that utilize branched-chain amino acids following water shortage in Arabidopsis. Plant Cell Environ. 2016, 39, 1304-1319. [CrossRef]

125. Chmielewska, K.; Rodziewicz, P.; Swarcewicz, B.; Sawikowska, A.; Krajewski, P.; Marczak, L.; Ciesiolka, D.; Kuczynska, A.; Mikolajczak, K.; Ogrodowicz, P.; et al. Analysis of drought-induced proteomic and metabolomic changes in barley (Hordeum vulgare L.) leaves and roots unravels some aspects of biochemical mechanisms involved in drought tolerance. Front. Plant Sci. 2016, 7, 1108. [CrossRef] [PubMed]

126. Bowne, J.B.; Erwin, T.A.; Juttner, J.; Schnurbusch, T.; Langridge, P.; Bacic, A.; Roessner, U. Drought responses of leaf tissues from wheat cultivars of differing drought tolerance at the metabolite level. Mol. Plant. 2012, 5, 418-429. [CrossRef] [PubMed]

127. Wang, W.; Vinocur, B.; Shoseyov, O.; Altman, A. Role of plant heat-shock proteins and molecular chaperones in the abiotic stress response. Trends Plant Sci. 2004, 9, 244-252. [CrossRef] [PubMed]

128. Howell, S.H. Endoplasmic reticulum stress responses in plants. Annu. Rev. Plant Biol. 2013, 64, 477-499. [CrossRef]

129. Cho, E.K.; Hong, C.B. Over-expression of tobacco NtHSP70-1 contributes to drought-stress tolerance in plants. Plant Cell Rep. 2006, 25, 349-358. [CrossRef]

130. Deshmukh, R.K.; Sonah, H.; Belanger, R.R. Plant aquaporins: Genome-wide identification, transcriptomics, proteomics, and advanced analytical tools. Front. Plant Sci. 2016, 7, 1896. [CrossRef]

131. Hand, S.C.; Menze, M.A.; Toner, M.; Boswell, L.; Moore, D. LEA proteins during water stress: Not just for plants anymore. Annu. Rev. Physiol. 2011, 73, 115-134. [CrossRef]

132. Prashanth, S.R.; Sadhasivam, V.; Parida, A. Over expression of cytosolic copper/zinc superoxide dismutase from a mangrove plant Avicennia marina in indica rice var Pusa Basmati-1 confers abiotic stress tolerance. Transgenic Res. 2008, 17, 281-291. [CrossRef]

133. Zhang, Z.; Zhang, Q.; Wu, J.; Zheng, X.; Zheng, S.; Sun, X.; Qiu, Q.; Lu, T. Gene knockout study reveals that cytosolic ascorbate peroxidase 2 (OsAPX2) plays a critical role in growth and reproduction in rice under drought, salt and cold stresses. PLoS ONE 2013, 8, e57472.

134. Li, S. Redox modulation matters: Emerging functions for glutaredoxins in plant development and stress responses. Plants 2014, 3 , 559-582. [CrossRef]

135. Guo, Y.; Huang, C.; Xie, Y.; Song, F.; Zhou, X.A. tomato glutaredoxin gene SlGRX1 regulates plant responses to oxidative, drought and salt stresses. Planta 2010, 232, 1499-1509. [CrossRef] [PubMed]

136. Wu, Q.; Hu, Y.; Sprague, S.A.; Kakeshpour, T.; Park, J.; Nakata, P.A.; Cheng, N.; Hirschi, K.D.; White, F.F.; Park, S. Expression of a monothiol glutaredoxin, AtGRXS17, in tomato (Solanum lycopersicum) enhances drought tolerance. Biochem. Biophys. Res. Commun. 2017, 491, 1034-1039. [CrossRef] [PubMed]

137. Du, M.; Ding, G.; Cai, Q. The transcriptomic responses of Pinus massoniana to drought stress. Forests 2018, 9, 326. [CrossRef]

138. Dong, B.; Wu, B.; Hong, W.; Li, X.; Li, Z.; Xue, L.; Huang, Y. Transcriptome analysis of the tea oil camellia (Camellia oleifera) reveals candidate drought stress genes. PLOS ONE 2017, 12, e0181835.

139. Zhang, Q.; Liu, H.; Wu, X.; Wang, W. Identification of drought tolerant mechanisms in a drought-tolerant maize mutant based on physiological, biochemical and transcriptomic analyses. BMC Plant Biol. 2020, 20, 315. [CrossRef]

140. Jiang, C.; Li, X.; Zou, J.; Ren, J.; Jin, C.; Zhang, H.; Yu, H.; Jin, H. Comparative transcriptome analysis of genes involved in the drought stress response of two peanut (Arachis hypogaea L.) varieties. BMC Plant Biol. 2021, 21, 64. [CrossRef] 
141. Tahmasebi, A.; Niazi, A. Comparison of Transcriptional Response of $C_{3}$ and $C_{4}$ Plants to Drought Stress Using Meta-Analysis and Systems Biology Approach. Front. Plant Sci. 2021, 12, 668736. [CrossRef]

142. Heijden, M.G.A.V.D.; Bardgett, R.D.; Straalen, N.M.V. The unseen majority: Soil microbes as drivers of plant diversity and productivity in terrestrial ecosystems. Ecol. Lett. 2008, 11, 296-310. [CrossRef] [PubMed]

143. Cavicchioli, R.; William, J.R.; Timmis, K.N.; Azam, F.; Bakken, L.R.; Baylis, M.; Behrenfeld, M.J.; Boetius, A.; Boyd, P.W.; Classen, A.T.; et al. Scientists' warning to humanity: Microorganisms and climate change. Nat. Rev. Microbiol. 2019, 17, 569-586. [CrossRef]

144. Ullah, A.; Akbar, A.; Luo, Q.; Khan, A.H.; Manghwar, H.; Shaban, M.; Yang, X. Microbiome Diversity in Cotton Rhizosphere Under Normal and Drought Conditions. Microb. Ecol. 2019, 77, 429-439. [CrossRef]

145. Nannipieri, P.; Ascher, J.; Ceccherini, M.T.; Landi, L.; Pietramellara, G.; Renella, G.; Valori, F. Microbial diversity and microbial activity in the rhizosphere. Cienc. Suelo 2007, 25, 89-97.

146. Preece, C.; Peñuelas, J. Rhizodeposition under drought and consequences for soil communities and ecosystem resilience. Plant Soil 2016, 409, 1-17. [CrossRef]

147. Yang, Z.; Zhou, B.; Chen, Q.; Ge, X.; Shi, Y. Effects of drought on root architecture and non-structural carbohydrate of Cunninghamia lanceolata. Acta Ecol. Sin. 2018, 38, 6729-6740.

148. Dai, L.; Zhang, G.; Yu, Z.; Ding, H.; Xu, Y.; Zhang, Z. Effect of drought stress and developmental stages on microbial community structure and diversity in peanut rhizosphere soil. Int. J. Mol. Sci. 2019, 20, 2265. [CrossRef] [PubMed]

149. Kumar, A.; Singh, S.; Gaurav, A.K.; Srivastava, S.; Verma, J.P. Plant growth-promoting bacteria: Biological tools for the mitigation of salinity stress in plants. Front. Microbiol. 2020, 11, 1216. [CrossRef]

150. Khadka, R.B.; Uphoff, N. Effects of Trichoderma seedling treatment with system of rice intensification management and with conventional management of transplanted rice. PeerJ 2019, 7, 5877. [CrossRef]

151. Arun, K.D.; Sabarinathan, K.G.; Gomathy, M.; Kannan, R.; Balachandar, D. Mitigation of drought stress in rice crop with plant growth-promoting abiotic stress-tolerant rice phyllosphere bacteria. J. Basic Microbiol. 2020, 60, 768-786. [CrossRef]

152. Alamgir, A.N.M. Phytoconstituents-Active and Inert Constituents, Metabolic Pathways, Chemistry and Application of Phytoconstituents, Primary Metabolic Products, and Bioactive Compounds of Primary Metabolic Origin. In Therapeutic Use of Medicinal Plants and Their Extracts; Rainsford, K.D., Ed.; Progress in Drug Research; Springer: Cham, Switzerland, 2018; Volume 74, pp. 25-164.

153. Shukla, N.; Awasthi, R.P.; Rawat, L.; Kumar, J. Biochemical and physiological responses of rice (Oryza sativa L.) as influenced by Trichoderma harzianum under drought stress. Plant Physiol. Biochem. 2012, 54, 78-88. [CrossRef]

154. Etesami, H.; Maheshwari, D.K. Use of plant growth promoting rhizobacteria (PGPRs) with multiple plant growth promoting traits in stress agriculture: Action mechanisms and future prospects. Ecotoxicol. Environ. Saf. 2018, 156, 225-246. [CrossRef]

155. Egamberdieva, D.; Reckling, M.; Wirth, S. Biochar-based Bradyrhizobium inoculum improves growth of lupin (Lupinus angustifolius L.) under drought stress. Eur. J. Soil Biol. 2017, 78, 38-42. [CrossRef]

156. Ngumbi, E.; Kloepper, J. Bacterial-mediated drought tolerance: Current and future prospects. Appl. Soil Ecol. 2016, 105, 109-125. [CrossRef]

157. Enebe, M.C.; Babalola, O.O. The influence of plant growth-promoting rhizobacteria in plant tolerance to abiotic stress: A survival strategy. Appl. Microbiol. Biotechnol. 2018, 102, 7821-7835. [CrossRef]

158. Vejan, P.; Abdullah, R.; Khadiran, T.; Ismail, S.; Boyce, A.N. Role of plant growth promoting rhizobacteria in agricultural sustainability-a review. Molecules 2016, 21, 573. [CrossRef] [PubMed]

159. Chandra, D.; Srivastava, R.; Gupta, V.V.S.R.; Franco, C.M.M.; Sharma, A.K. Evaluation of ACC-deaminase-producing rhizobacteria to alleviate water-stress impacts in wheat (Triticum aestivum L.) plants. Can. J. Microbiol. 2019, 65, 387-403. [CrossRef]

160. Zafar-Ul-Hye, M.; Danish, S.; Abbas, M.; Ahmad, M.; Munir, T.M. ACC deaminase producing PGPR Bacillus amyloliquefaciens and Agrobacterium fabrum along with biochar improve wheat productivity under drought stress. Agronomy 2019, 9, 343. [CrossRef]

161. Naseem, H.; Ahsan, M.; Shahid, M.A.; Khan, N. Exopolysaccharides producing rhizobacteria and their role in plant growth and drought tolerance. J. Basic Microbiol. 2018, 58, 1009-1022. [CrossRef]

162. Sharifi, R.; Ryu, C.M. Revisiting bacterial volatile-mediated plant growth promotion: Lessons from the past and objectives for the future. Ann. Bot. 2018, 122, 349-358. [CrossRef]

163. El-Daim, I.A.A.; Bejai, S.; Meijer, J. Bacillus velezensis 5113 induced metabolic and molecular reprogramming during abiotic stress tolerance in wheat. Sci. Rep. 2019, 9, 16282. [CrossRef]

164. Goswami, M.; Deka, S. Plant growth-promoting rhizobacteria- alleviators of abiotic stresses in soil: A review. Pedosphere 2020, 30, 40-61. [CrossRef]

165. Bano, Q.; Ilyas, N.; Bano, A.; Zafar, N.; Akram, A.; Hassan, F. Effect of Azospirillum inoculation on maize (Zea mays L.) under drought stress. Pak J. Bot. 2013, 45, 13-20.

166. Vardharajula, S.; Zulfikar Ali, S.; Grover, M.; Reddy, G.; Bandi, V. Drought-tolerant plant growth promoting Bacillus spp.: Effect on growth, osmolytes, and antioxidant status of maize under drought stress. J. Plant Int. 2011, 6, 1-14.

167. Sandhya, V.; Ali, S.K.Z.; Minakshi, G.; Reddy, G.; Venkateswarlu, B. Alleviation of drought stress effects in sunflower seedlings by the exopolysaccharides producing Pseudomonas putida strain GAP-P45. Biol. Fertil. Soils. 2009, 46, 17-26. [CrossRef]

168. Lim, J.H.; Kim, S.D. Induction of drought stress resistance by multi-functional PGPR Bacillus licheniformis K11 in pepper. Plant Pathol. J. 2013, 29, 201-208. [CrossRef] [PubMed]

169. Figueiredo, M.V.; Burity, H.A.; Martínez, C.R.; Chanway, C.P. Alleviation of drought stress in the common bean (Phaseolus vulgaris L.) by co-inoculation with Paenibacillus polymyxa and Rhizobium tropici. Appl. Soil Ecol. 2008, 40, 182-188. [CrossRef] 
170. Staudinger, C.; Mehmeti-Tershani, V.; Gil-Quintana, E.; Gonzalez, E.M.; Hofhansl, F.; Bachmann, G.; Wienkoop, S. Evidence for a rhizobia-induced drought stress response strategy in Medicago truncatula. J. Proteom. 2016, 136, 202-213. [CrossRef]

171. Kasim, W.A.; Osman, M.E.; Omar, M.N.; Abd El-Daim, I.A.; Bejai, S.; Meijer, J. Control of drought stress in wheat using plant-growth-promoting bacteria. J. Plant Growth Regul. 2013, 32, 122-130. [CrossRef]

172. Ma, Y.; Rajkumar, M.; Zhang, C.; Freitas, H. Inoculation of Brassica oxyrrhina with plant growth promoting bacteria for the improvement of heavy metal phytoremediation under drought conditions. J. Hazard. Mater. 2014, 320, 36-44. [CrossRef] [PubMed]

173. Tiwari, S.; Lata, C.; Chauhan, P.S.; Nautiyal, C.S. Pseudomonas putida attunes morphophysiological, biochemical and molecular responses in Cicer arietinum L. during drought stress and recovery. Plant Physiol. Biochem. 2016, 99, 108-117. [CrossRef]

174. Sherameti, I.; Tripathi, S.; Varma, A.; Oelmuller, R. The root-colonizing endophyte Pirifomospora indica confers drought tolerance in Arabidopsis by stimulating the expression of drought stress-related genes in leaves. Mol. Plant-Microbe Interact. 2008, $21,799-807$. [CrossRef]

175. Hussain, M.B.; Zahir, Z.A.; Asghar, H.N.; Asgher, M. Can catalase and exopolysaccharides producing rhizobia ameliorate drought stress in wheat? Int. J. Agric. Biol. 2014, 16, 3-13.

176. Behrooz, A.; Vahdati, K.; Rejali, F.; Lotfi, M.; Sarikhani, S.; Leslie, C. Arbuscular mycorrhiza and plant growth-promoting bacteria alleviate drought stress in walnut. HortScience 2019, 54, 1087-1092. [CrossRef]

177. Morsy, M.; Cleckler, B.; Armuelles-Millican, H. Fungal endophytes promote tomato growth and enhance drought and salt tolerance. Plants 2020, 9, 877. [CrossRef] [PubMed]

178. Liao, X.; Chen, J.; Guan, R.; Liu, J.; Sun, Q. Two arbuscular mycorrhizal fungi alleviates drought stress and improves plant growth in Cinnamomum migao seedlings. Mycobiology 2021, 49, 396-405. [CrossRef]

179. Azad, K.; Kaminskyj, S.A. fungal endophyte strategy for mitigating the effect of salt and drought stress on plant growth. Symbiosis 2016, 68, 73-78. [CrossRef]

180. Budak, H.; Kantar, M.; Yucebilgili Kurtoglu, K. Drought tolerance in modern and wild wheat. Sci. World. J. 2013, 4, 66-75. [CrossRef] [PubMed]

181. Oh, S.J.; Kim, Y.S.; Kwon, C.W.; Park, H.K.; Jeong, J.S.; Kim, J.K. Overexpression of the transcription factor AP37 in rice improves grain yield under drought conditions. Plant Physiol. 2013, 150, 1368-1379. [CrossRef] [PubMed]

182. Valliyodan, B.; Nguyen, H.T. Understanding regulatory networks and engineering for enhanced drought tolerance in plants. Curr. Opin. Plant Biol. 2006, 9, 189-195.

183. Trujillo, L.E.; Sotolongo, M.; Menendez, C.; Ochogavia, M.E.; Coll, Y.; Hernandez, I.; Hernandez, L. SodERF3, a novel sugarcane ethylene responsive factor (ERF), enhances salt and drought tolerance when over expressed in tobacco plants. Plant Cell Physiol. 2008, 49, 512-525. [CrossRef] [PubMed] 